Florida International University FIU Digital Commons

\title{
Measuring Impacts of Neem Oil and Amitraz on Varroa destructor and Apis Mellifera in Different Agricultural Systems of South Florida
}

Stephany C. Alvarez-Ventura

Florida International University, scaalvar@fiu.edu

DOI: $10.25148 /$ etd.FI11120503

Follow this and additional works at: https://digitalcommons.fiu.edu/etd

\section{Recommended Citation}

Alvarez-Ventura, Stephany C., "Measuring Impacts of Neem Oil and Amitraz on Varroa destructor and Apis Mellifera in Different Agricultural Systems of South Florida" (2011). FIU Electronic Theses and Dissertations. 490.

https://digitalcommons.fiu.edu/etd/490 


\title{
FLORIDA INTERNATIONAL UNIVERSITY
}

Miami, FL

\section{MEASURING IMPACTS OF NEEM OIL AND AMITRAZ ON VARROA \\ DESTRUCTOR AND APIS MELLIFERA IN DIFFERENT AGRICULTURAL SYSTEMS OF SOUTH FLORIDA}

\author{
A thesis submitted in partial fulfillment of the \\ requirements for the degree of \\ MASTER OF SCIENCE \\ in
}

ENVIRONMENTAL STUDIES

by

Stephany Alvarez-Ventura

2011 


\section{To: Dean Kenneth Furton}

College of Arts and Sciences

This thesis, written by Stephany Alvarez-Ventura, and entitled Measuring Impacts of Neem Oil and Amitraz on Varroa destructor and Apis Mellifera in Different Agricultural Systems of South Florida, having been approved in respect to style and intellectual content, is referred to you for judgment.

We have read this thesis and recommend that it be approved.

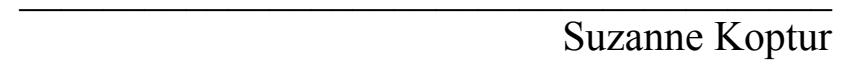

Krishnaswamy Jayachandran, Co-Major Professor

Mahadev Bhat, Co-Major Professor

Date of Defense: September $9^{\text {th }}, 2011$

The thesis of Stephany Alvarez-Ventura is approved.

Dean Kenneth Furton
College of Arts and Sciences

Florida International University, 2011 


\section{DEDICATION}

I dedicate this thesis to my children, my husband, and both of our families.

Without their love, support, and encouragement I could not have accomplished this

journey. 


\section{ACKNOWLEDGMENTS}

I would like to that my major advisors, Dr. Krish Jayachandran (Dr. Jay) and Dr. Mahadev Bhat, for their mentorship and providing me an abundance of opportunities, including the freedom to participate in this agroecological research. I also wish to thank the members of my committee, Dr. Suzanne Koptur and Dr. Jeffery Onsted, for their guidance and continued support. I woud like to give a special thanks to Steve Corniffe, for using his hives and for his unconditional help in the field. This manuscript would not be possible without the funding opportunity provided by the USDA's Hispanic Serving Institution (2008-38422-19209) and the Multicultural Scholars (2007-38413-17816 and 2009-38413-05236) grant. I'd like to acknowledge all of my lab friends, especially Priyanka Narendar, Pushpa Sharma, Beyte Barrios, Andrew Jungman, Thelma Velez, and Brett Pierce, and Andrea Roofe, for all of their help in making this journey not only possible, but also enjoyable. Finally, to my Lord and Savior, Jesus Christ, for saving me from bee stings and aligning my time to accomplish this milestone in my life. 


\author{
ABSTRACT OF THE THESIS \\ MEASURING IMPACTS OF NEEM OIL AND AMITRAZ ON VARROA \\ DESTRUCTOR AND APIS MELLIFERA IN DIFFERENT AGRICULTURAL \\ SYSTEMS OF SOUTH FLORIDA
}

by

Stephany Alvarez-Ventura

Florida International University, 2011

Miami, Florida

Professor Krish Jayachandran and Professor Mahadev Bhat, Major Professors This thesis analyzes mixtures of neem oil and amitraz as alternative control for Varroa destructor, a major pest of Apis mellifera, under different agricultural settings. In organic and conventional farms, the different treatments were applied in colonies to determine impacts on mite loss, colony strength, and honey yield. The results demonstrated neem to have the least effective control on mite mortality, while the neem and amitraz mixture had the most. Furthermore, no long term impacts on queen fecundity and colony strength were noticed between treatments. However, queen fecundity and honey yield was significantly higher in sites with higher flower abundance and diversity, demonstrating higher colony strength in these sites. Further understanding of the relationship between apiculture and agricultural management is vital for conservation of pollinator health and associated habitats. 


\section{TABLE OF CONTENTS}

$\begin{array}{ll}\text { CHAPTER PAGE } & \text { PAT }\end{array}$

I. Introduction $\quad 1$

II. Literature Review $\quad 4$

2.1 Importance of studying honeybees and agricultural management 4

2.2 Apis mellifera 6

2.3 Varroa destructor $\quad 7$

2.4 Methods of Controlling Varroa Mites 10

2.4.1Conventional Treatments 11

$\begin{array}{ll}2.4 .2 \text { Amitraz } & 12\end{array}$

2.4.3 Essential Oils 13

$\begin{array}{ll}2.4 .4 \mathrm{Neem} & 14\end{array}$

III. Methodology 15

3.1 Selection of Study Sites $\quad 15$

$\begin{array}{ll}3.2 \text { Essential oils and mixtures preparation } & 16\end{array}$

$\begin{array}{ll}3.3 \text { Treatment procedure } & 17\end{array}$

$\begin{array}{ll}3.4 \text { Sampling method } & 17\end{array}$

3.4.1 Materials 17

3.4.2 Queen fecundity 18

3.4.3 Measurement of mite levels $\quad 18$

3.4.4 Honey yield 20

3.5 Assessment of the efficacy levels 20

IV. Results 22

4.1 Treatment effectiveness $\quad 22$

4.2 Changes in queen fecundity $\quad 29$

4.3 Honey production 33

V. Discussion

5.1 Treatment effectiveness 36

5.2 Implications on queen fecundity 38

5.3 Differences in agricultural management and honey production 39

VI. Conclusions $\quad 42$

$\begin{array}{ll}\text { REFERENCES } & 44\end{array}$ 


\section{LIST OF TABLES}

TABLE

PAGE

1. Treatment preparations

2. Rate of efficacy for each site and treatment type

3. Initial mite levels based on treatment type

4. Initial mite levels based on type of site

5. Multiple Comparison of dead mites in sticky board (after first treatment)

6. Comparison of treatments to untreated for organic and conventional sites

7. Chi-Square Test demonstrating difference between $\mathrm{C} 1$ and $\mathrm{O} 3$ in queen fecundity change

8. One-way ANOVA demonstrating differences in improvement of honey by each site 


\section{TABLE OF FIGURES}

FIGURE

PAGE

1. Honey bee and varroa mite life cycle

2. Site locations in Southwest Miami Dade

3. Count of mite mortality after different treatments

4. Mean value of queen fecundity before and after treatment period at each site

5. Mean value of queen fecundity before treatment and after five weeks

6. Total count of queen fecundity before and after treatment period

7. Chi-square test showing difference in queen fecundity based on site

8. Total honey yield before treatment and after season ( 5 months)

9. Improvement in honey weight for each site 


\section{Introduction}

The decline of pollinators in recent decades is threatening the structure and function of natural and agricultural ecosystems. Pollinators provide essential ecosystem services by aiding plant and tree reproduction that require pollination assistance. Large scale production of food crops in agricultural systems is in many cases, only possible with the assistance of pollinators, primarily honeybees (USDA 2009). Recent declines in many of these pollinators have been blamed on land-use changes, diseases, chemicals and climate change (Mullin 2010). Honey bees are proving to be excellent indicators of the state of an ecosystem: Not only do honey bees contribute significant economic values to humans, but also the trapped information found in the form of honey, wax, and pollen can provide information on impacts of xenobiotics in the surrounding environment (Devillers and Pham-Delegue 2002).

Valued for the honey they make and pollination services they perform, honeybees, Apis mallifera, are the most exploited of all pollinators. While honey production is a 330 million dollar industry in the United States (US), their pollination service brings in $\$ 15-20$ billion in added crop value (USDA 2009). Produce such as watermelons, berries, nuts (mainly almonds), and many other fruits and vegetables need proper pollination in order to bear fruit and ensure larger yields. According to the United States Department of Agriculture (USDA) about one third of the human diet comes from pollinated crops, and the honeybee is responsible for $80 \%$ of that pollination. Managing these bees, however, is proving to be much more difficult these days.

Managed colonies have declined by $50 \%$ in the last 50 years, in large part because of the infestation of the Varroa mite, Varroa destructor (USDA et al. 2008). Controlling 
this pest has become difficult because of rising costs of synthetic acaricides, along with residue issues and developed resistance from the mites, which has led to great losses in many colonies (USDA 2009). In addition to pests, the recent disappearance of significant number of colonies worldwide, termed Colony Collapse Disorder (CCD), is directing many beekeepers to leave the practice, which may affect agricultural production systems and food prices (USDA 2009). Therefore, adaptive management approaches, such as the 2008 Farm Bill, are currently being formulated to improve pollinator habitat and function in agricultural settings to protect honey bees and other pollinators. Likewise, beekeepers are looking for alternative acaricides, such as essential oils, to control Varroa in light of the large colony declines. My study focuses on reducing dependence on mite chemical controls while touching on possible implications drawn from agricultural management.

My thesis analyzed mixtures of Neem oil and amitraz as alternative mite controls under different agricultural settings. The first objective of this study is to determine Neem alone or in conjunction with amitraz (a chemical insecticide) is most effective in controlling mites without negatively impacting honey bees through the measurement colony strength, honey yield and mite loss. Although it is hoped that neem will provide sufficient control, it is hypothesized that the neem and amitraz (NA) mixture will be most effective at controlling mite levels. However, impacts to the colony, particularly queen production, are unknown. The purpose of using these substances is to find an effective measure at controlling mite levels with essential oils in order for beekeepers discontinue the increase of chemical applications to hives.

The second objective of this study is to determine how different agricultural settings may influence colony health and response to acaricides applications. To measure 
this, the experiment was carried out on two organic farms and two conventional farms. The purpose of choosing several sites is to monitor possible impacts from agricultural management on colony strength under these different treatments. Although queen production was not expected to be different between sites, it was hypothesized that honey yields, which demonstrate colony strength, would be different between organic farms and conventional farms. Therefore, this study is significant in that it may demonstrate how multiple stressors (mite populations as well as agricultural management) may be linked to colony health and possibly, affect yields. My study will provide new information on acaricide effectiveness, and will also demonstrate the relationship between site selection and colony strength. The information gained on acaricide effectiveness can be used by beekeepers to control Varroa mite, and the relationship between agriculture and apiculture management may be useful in assisting the development of USDA's pollinator conservation programs' initiatives. 


\section{Literature Review}

\section{Importance of studying honeybees and agricultural management}

The loss of natural pollinators as a result of habitat loss and pesticide application has forced farmers to depend on domesticated honey bees for pollination. While natural habitats can provide full pollinator services, conventional agriculture clears these lands and adds pesticide amendments for crop production, greatly reducing habitat availability for pollinators and killing beneficial insects (Kremen et al. 2002). Honey bees are the most efficient pollinators of $80 \%$ of the crops in the United States (USDA 2009), and farmers prefer their services because they greatly improve crop yields, and can be transported when pesticides are applied. Until native pollinators and their habitats can be better protected or restored, we will continue to depend on managed honey bees. With growing populations and demand for food products, honey bees are in high demand to provide their honey and pollination services.

With honey bees and other pollinators in serious declines, it is imperative that we understand how to improve their well being. While many pollinators can be used for studying environmental impacts of agricultural management, honey bees are the best qualified because not only can they trap dust particles, including bioavailable contaminates, on their body hairs, but they can also provide clues to environmental state through their honey, wax, and royal jelly (Devillers \& Pham-Delegue 2002). The high economic importance of these insects provides the political will to study what environmental impacts seem to be affecting them. 
Impacts of land use on honey bees and other pollinators must be considered to reduce the current decline rates of these pollinators. The management of modern pollinated-dependent agriculture is, many times, only effective in conjunction with several honey bee colonies. For this reason, many farmers rent colonies in order to pollinate their large monocultures. Habitat loss as a result of agriculture conversion results in less diversity in food sources for pollinators. A study done in Yolo County, California observed pollination by native bees in several agricultural management regimes (organic versus conventional) and proximity to natural habitat (Kremen et al. 2002). The study observed that full pollination services can be met by native bees in organic farms near natural habitat, including crops that require heavy pollination (e.g., watermelon). Every other farm, however, could not meet pollination requirements because of reduced diversity and species abundance of pollinators (Kremen et al. 2002). The authors noted that full pollination services provided by native bees would be destroyed by continued degradation of natural habitat. Furthermore, it indicated that farmers can become resilient to the current declines in managed hives by conserving and restoring bee habitats through sustainable farming practices. The impact agricultural management has on pollination services demonstrates the need to observe colonies in agricultural sites in order to determine whether agricultural management, on the basis of flower diversity and availability, influences colony strength. This information can demonstrate that honey bees can serve as environmental indicators for agricultural impacts on other pollinators and, as per the 2008 Farm Bill, assist in the formulation of pollinator protection protocols in agricultural sites. 


\section{Apis mellifera}

Apis mellifera falls under the cavity-nesting honey bee, subgenus Apis, which originated in South/Southeast Asia. While some species of honeybees nest in single, exposed combs, Apis mellifera make multiple combs, making them easily manageable colonies. In the US, the only known honeybee ancestor, Apis nearctica, was recently identified from a single 14-million-year old specimen in Nevada (Engel 2009). The commercial honey bee (as it is now known) was introduced into the US more than 300 years ago. This particular species has been bred for their efficiency in honey production, pollination services and overall docile disposition. While the native bee of North America is the bumblebee (Bombus), their colonies are not as extensive as the honeybees, lasting usually only a season, and therefore serve as poor honey producers. However, their ability to pollinate at high latitudes and using the buzz pollination technique make bumblebees more efficient at pollinating some crops, like green-house grown tomatoes and peppers. There are also nonnative bees used in agriculture, like the Eurasian leafcutter bee, which has been recently domesticated for its effectiveness in pollinating alfalfa; still, $80 \%$ of commercial crops that require pollinators are pollinated by the Western honey bee (USDA 2009).

A typical established honeybee colony is made up of one mated queen, 0-200 male drones, and 20-200 thousand small sterile female workers. The drones' primary function is mating with virgin queens. On the other hand, workers clean and rebuild the hive, cap/uncap and tend larvae cells, gather nectar, pollen, and propolis, make honey, and defend the colony. The queen can lay around 1500 eggs/day and can last up to two years (depending on the spermatozoids). The queen communicates with colony members 
through pheromone secretions that, among other functions, signal attacks on the colony or promote swarming. Through their egg laying patterns, queens can indicate colony strength and therefore adequate honey production and pollination services.

The life cycle of honeybees is different for each caste. The metamorphic process of worker bees take 21 days and begin with fertilized eggs deposited at the bottom of a cell. After three days, the egg hatches into a first-instar larva and is fed by nurse bees. Throughout seven days in this stage, the first-instar larva grows through successive molting stages. The brood is then sealed by the nurse bees to allow nine days of pupa growth. The adult worker bee chews its way out its cell after spending one day as an unemerged adult. Complete metamorphosis in drones is similar to workers; however it takes 3 days longer to fully develop due to the larger size of the cell. Queens take only 16 days to develop from egg to adult as a result of the nutritious royal jelly feeding.

\section{Varroa destructor}

The Varroa mite is an external mite that can reproduce in honey bee colonies. The Varroa mite attaches to the body of bees and sucks their hemolymph while transmitting viruses, which ultimately weakens or kills the bees. The Varroa mite has become the most serious of honey bee pests leading to declines in honey bee colonies, honey yields, and crop pollination (USDA 2009). Although the Varroa mite was originally described as Varroa jacobsoni in 1904, genotypic variation found in the mitochondrial DNA of the western honey bees and North Asia's Apis cerana gave rise to the new species, Varroa destructor (Anderson and Trueman 2000). According to Anderson and Trueman (2000), the 18 different haplotypes found explain bee susceptibility to the mite. On the basis of 
their findings and other studies (Amrine et al. 1997; Anderson \& Trueman 2000; Colin et al. 1999; Vargas-Sarmiento 2000), it is assumed the mites in this study are Varroa destructor.

The Varroa mite's morphology and biology make it an excellent parasite of the honey bee. The size of the female body is $1.0-1.8 \mathrm{~mm}$ long by $1.5-1.9 \mathrm{~mm}$ wide and is reddish dark brown in color, while the males are $0.7 \mathrm{~mm}$ by $7 \mathrm{~mm}$, and yellowish-gray in color (Vargas-Sarmiento 2000). It is dorso-ventrally flatten with a transverse oval shape which allows them to fit between the abdominal sternites of adult bees. The mites feed on the honey bee's hemolymph through their piercing and sucking mouthparts while transmitting viruses such as deformed wing virus (DWV), acute bee paralysis virus (APV), slow paralysis virus (SPV), and Israeli acute paralysis virus (IAPV) (USDA 2009).

The life cycle of the mite also aids the mite's parasitism on the honey bee (Figure 1). A female mite can detach itself from a bee host or craw out of one cell and enter a new cell just before it is capped. If the cocoon has not been spun, the female mite begins feeding and lays her eggs. The first egg, which usually develops into a male, is laid after 60 hours of the cell being capped. Then, every 30 hours the mother lays an egg which develops into a female; she can lay between 1-5 female eggs in total. The immature mites feed on a wound which their mother opens on the developing bee. The eggs develop into larvae and then into a pronymph within 60-65 hours, after which the pronymph develops into a deutonymph and then into an adult. The process from egg to adult is 5-6 days for males and 7-8 days for female. Once the adult bee emerges from the cell, immature female mites will die but adult female mites will enter new cells and begin the 
reproductive cycle again. Mite reproduction is more successful and preferred in drone cells than worker cells because of the longer pre and post capping periods, larger cells, higher protein content, and chemical composition of cuticle (Rosenkranz et al. 1993).

Figure 1: Honey bee and Varroa mite life cycle
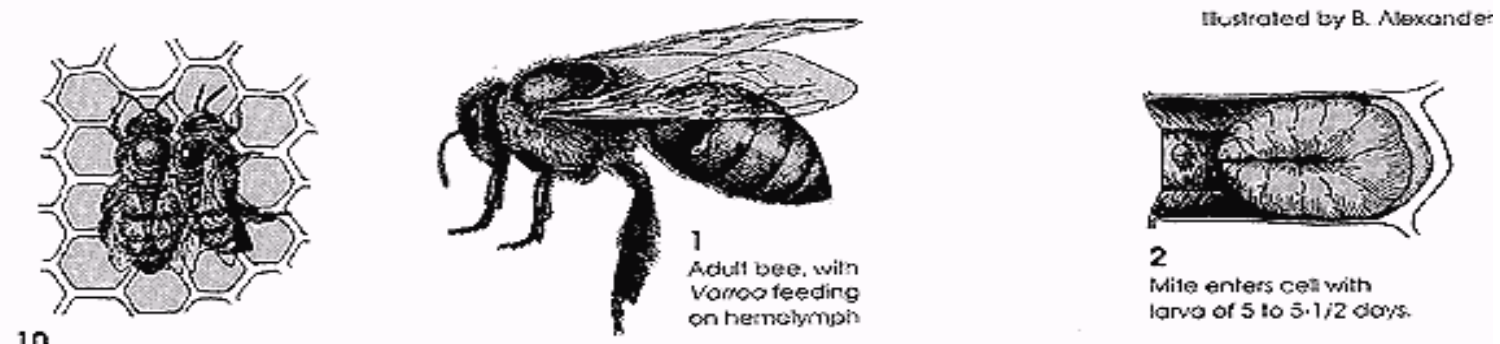

Mites transter through

close contco: between bees.

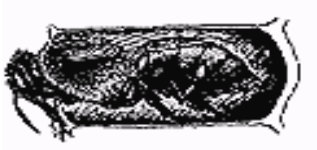

9

Achill temoles leave cent with emerging $D B C$. Male and immolure stages stoy in cell.
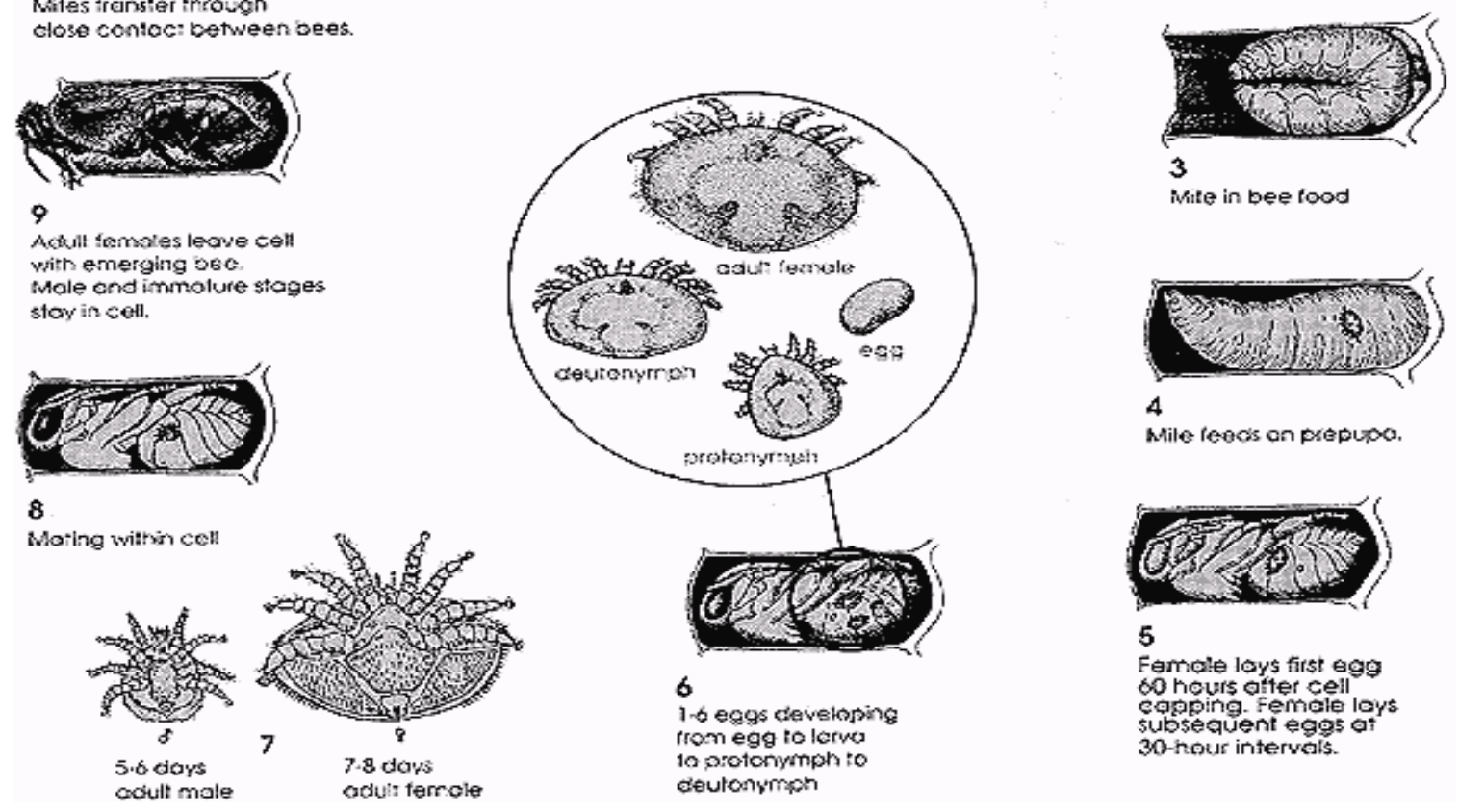
deutonymon

Diagram credit: "FAQs related to Varroa Mite” (from Biosecurity 2010)

The infestation of the Varroa destructor to the Apis mellifera brood is known as varroatosis (Ball 1988). By feeding on the bee's hemolymph, protein content and hemocytes can be reduced up to $50 \%$ and $30 \%$ respectively, which leads to weight loss 
and deformity in wings and limbs (Ball 1988). In addition, the viruses and other pathogens the mites transmit aid in reducing the bee's life span. Depending on the climate, season and level of infestation, the health of a honey bee colony can deteriorate within a few months' time (Corniffe, personal communication; Downey and Winston 2001). Evidence of infestation can be seen by inspecting the colony and visibly seeing the mites, or by observing deformity in wings or paralysis in the bees.

\section{Methods of Controlling Varroa Mites}

There are a variety of methods for controlling Varroa mite population in honey bee colonies. These include: bottom board inserts, worker and drone comb traps, chemical controls, and essential oils application. Bottom board inserts are boards (cardboard, paper, or sticky material) inserted on top of the bottom boards with the purpose of acting as a physical barrier between the bees and mites. These boards are usually coated with Vaseline, cooking spray, or other sticky substance to trap the mites and not allow them to re-infest the brood. Research has demonstrated this method to be effective at slowing the population growth of the mites but insufficient at controlling Varroa mites (Pettis and Shimanuki 1999). This research used bottom boards as a means of measuring the effectiveness of the treatments issued by counting the fallen morbid/dead mites on cooking spray coated board.

Worker and drone comb traps offer a different means of slowing mite population growth. These traps work differently. Drone comb traps work by removing drone brood but it is time consuming and may increase selection for worker brood preference; therefore impractical for large scale beekeeping and cannot completely replace chemical 
treatments (Delaplane 1997). Worker comb traps are different in that high temperatures or formic acid is used. Worker comb traps are preferred over drone traps because they can be used throughout the season and an infinite amount of brood can be used (Calis et al. 1999).

\section{Conventional Chemical Treatments}

Controlling Varroa mites is especially complicated as the mites prefer sealed brood during reproduction and are therefore protected from various treatments by the hive (Hoppe et al., 1989). In order to control mite and other pest infestations, beekeepers use a variety of chemical additives, primarily using the active acaricides fluvalinate(Apistan $($ ) $)$ and coumaphos (Checkmite $\left.{ }^{\circledR}\right)$, which have been shown to leave residues in over 95\% of honey, wax, and propolis samples (Bogdanov et al. 1998, Mullin et al. 2010). The use of the pyrethroid, fluvalinate, has also made the honey bees more susceptible to pesticides sprayed on crops, such as bifenthrin, and block detoxification mechanisms for some fungicides in bees (Pilling et al. 1995). Another study demonstrated that the combinations of some pesticides can increase toxicity in honeybees by 1,000 folds (Iwasa et al. 2004). This demonstrates a clear link between apiculture and agricultural management that affects colony health. Moreover, because of the misuse of the pesticides in many countries and states, including Florida, mites have developed resistance. These concerns have led to beekeepers to turn to other methods of controlling the mites. 


\begin{abstract}
Amitraz
Amitraz, a triazapentadiene compound part of the amidine family, was a chemical method approved for temporary use to control mites during the 1990s. Amitraz is classified as a Class III (slightly toxic) under the EPA guidelines. It has been used as an insecticide to control red spider mites, leaf miners, scale insects, and aphids, while on animals it is used to control ticks, mites, lice and other animal pests (Thomson 1983, Budavari 1989). Although Amitraz is lipophilic and can contaminate beeswax, it breaks down rapidly and is therefore usually below detection levels (Bogdanov et al. 1998, Smodis et al. 2010). While Amitraz was thought to be relatively non-toxic to bees (Thomson 1983, Briggs 1992), miss-use and health concerns have made this chemical illegal for use on honey bee colonies. Nevertheless, many beekeepers still use this chemical because it is easy to apply and works extremely well (Corniffe, personal communication). Lately, beekeepers have been increasing the application dosage (up to 3\% mixture). Research has demonstrated Amitraz resistance in some colonies (Elzen et al. 2000), so beekeepers are looking for ways to reduce their dependence on Amitraz while still controlling for mites.

In order to reduce mite resistance and wean off amitraz, a mixture of amitraz and essential oils has been proposed. Colin (1990) demonstrated that aerosol application of water emulsions of $1 \%$ thyme oil and $0.5 \%$ sage oil with $0.25 \%$ Amitraz solution removed $99 \%$ of mites. However, mites have shown resistance to these low amitraz levels but not to higher levels (Corniffe, personal communication).
\end{abstract}




\section{Essential Oils}

Essential oils are a natural, safer alternative to chemical control measures. Essential oils are highly volatile compounds that plants have evolved as a defense or reproduction mechanism (Rohloff 1999). Their constituent hydrocarbons, terpenes and phenylpropanes emit strong odors that attract insect pollinators while repelling phytophagous insects (Imdorf et al. 1999). Depending on cultivation and climatic conditions, plants develop different compositions of oil that determines its chemotype (Imdorf et al 1999). The final chemical composition of the essential oil can also be determined by extraction methods. They compare favorably to other mite treatments because they degrade rapidly, are usually nontoxic to non-target species, and less susceptible for insects developing resistance in comparison to other pesticides (Gerard et al. 1997, Imdorf et al. 1999).

While more than 150 essential oils have been screened, few remain viable at controlling mites without affecting honey bees (Imdorf et al. 1999). On the basis of a collection of studies, Imdorf et al. (1999) favored wintergreen oil as an excellent mite control measure (100\% mortality within 48 hours) with an attractant, non-lethal response by honeybees. Among the lethal results, onion, garlic, wormwood, thyme, oregano, and peppermint all resulted in $100 \%$ mite mortality within 72 hours, but also produced high bee mortality. Although thymol has shown to be toxic in both contact and respiration, and has been demonstrated to increase aggressiveness, stimulate robbing and affect colony development, it has become a leading mite control alternative under the name Apilife VAR ${ }^{\circledR}($ Imdorf et al 1999, Mautz 1982). In South Florida, using essential oils treatments can prove challenging. The higher temperatures rapidly releases the aroma trapped in the 
oil, which can agitate honey bees and may not provide long term protection against Varroa (Corniffe, personal communication).

\section{Neem}

Neem oil is an essential oil that deserves a closer look. Neem oil comes from the Indian neem tree, Azadirachta indica A. Juss. The medicinal values of the tree, particularly its anti-bacterial, anti-parasitic, anti-fungal, anti-protozoal and anti-viral properties, are commonly known in India. It is an approved natural pesticide for use on organic farms because of their low environmental persistence and is considered non-toxic to animals. Its main constituent, Azadirachtin, is thought to affect insects by ceasing intestinal function or creating hormonal dysfunction. While neem oil has not been widely studied for apiculture uses, the results vary with different studies. While one highly cited study indicates negative impact on colony health (Melathopoulos 2000), other studies state that by controlling multiple types of mites, neem oil can improve colony health. In a field study in Canada, $10 \%$ neem oil sprayed provided between $50-80 \%$ reductions in mite population, indicating possible uses for this oil in hive treatments (Melathopoulos 2000). However, Melathopoulos (2000) found that neem treatments caused a significant loss of queens and may be acutely toxic to immature bees. Both Colin (1990) and Melathopoulos (2000) found the oil to have a repellent effect on the bees and not useful as a sugar patty ${ }^{1}$ additive. On the other hand, Allam et al. (2003) and Liu (1995) both agree that low percentage of neem in patties can control other bee diseases (i.e., chalkbrood and Nosema) while controlling mites if the essential oil is evaporated. The multiple mite controls can reduce the need for additional chemicals and may aid in improved colony strength.

${ }^{1}$ Edible patties are made with shorting, sugar, and essential oils to control mite populations in honey bees 


\section{Methodology}

\section{Selection of Study Sites}

Four sites were used: two organic farms and two conventional farms. The farm sites were chosen because of relative similarities in farming practices (i.e., field crops and fruit trees) and size of farm. The first organic farm (O1) is located close to 191 Street and 137th Avenue, Southwest Miami, FL. This 15 acre farm contains fruit trees and field crops as well as high weed/wildflower availability. Neighboring site $\mathrm{O} 1$ is a conventional plant nursery, a conventional tomato field and residential areas. The first conventional farm $(\mathrm{C} 1)$ was selected because of its relatively close proximity to the organic farm. The conventional farm is located by 168 Street and SW 137 Avenue in Miami, FL. This 10 acre conventional farm contains a plantation of plantains with a smaller area for field crops, such as tomatoes and squash, and limited weeds/wildflowers availability. Located across six lanes of traffic is a pine rockland habitat with residential areas nearby. Sites 3 and 4 were located farther south in the Redlands area of Miami-Dade county. The second organic farm (O2) is located by 184 Avenue SW 248th St, in Homestead, FL. This 5 acre farm also contains fruit trees and a small area of field crops with wide weed/wildflower availability. Neighboring this site is the Fruit and Spice Park as well as other farms and nursery plantations that offer large flower availability. The second conventional farm (C2) is located by 258 Street and SW 152 Ave, in Homestead FL. This 2.5 acre farm consists of only field crops; however, farms of fruit trees border its fences with plant nurseries nearby. The actual site has limited weed/wildflower availability but area overall has a good abundance of these nectar sources. 
Figure 2: Site locations in Southwest Miami Dade.

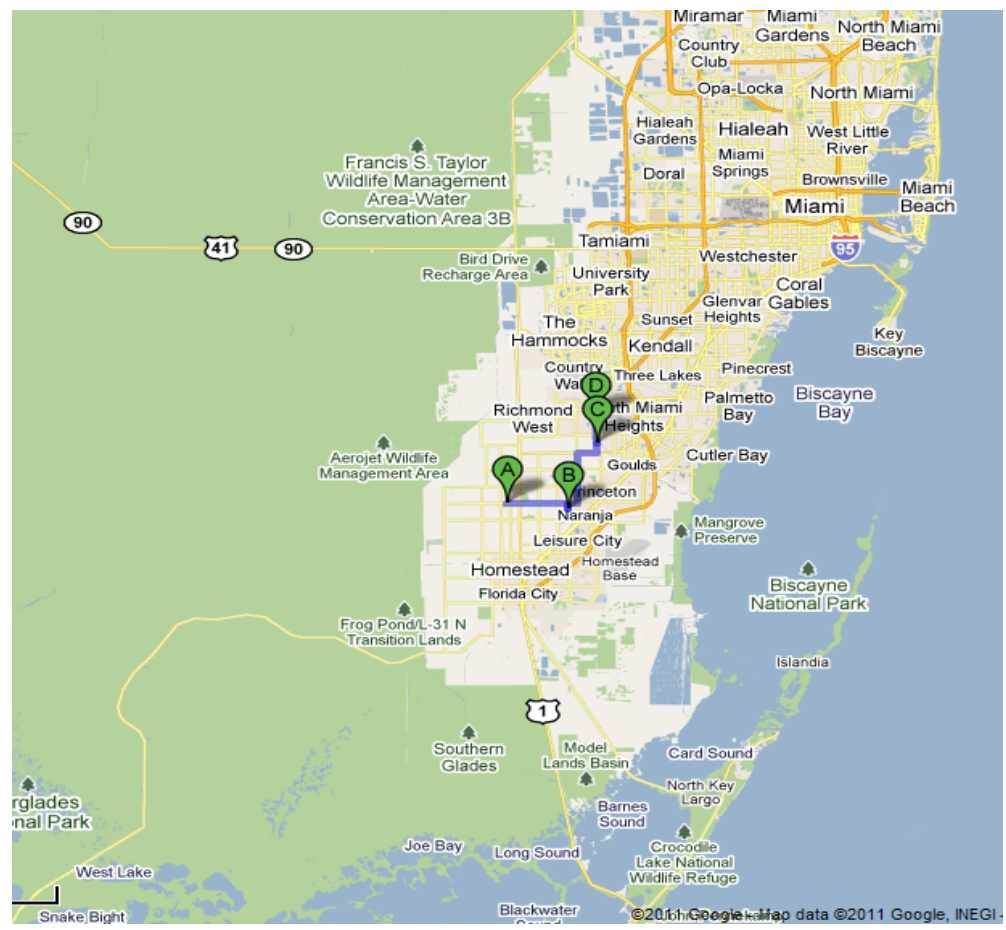

Legend:

A- $\mathrm{O} 2$

B- $\mathrm{C} 2$

C- $\mathrm{O} 1$

D-C1

\section{Preparation of essential oil and Amitraz mixtures}

Forty-eight hives were used in this experiment with 12 colonies at each site. Three colonies were used for each treatment type and three untreated hives served as control. Two batches of the mite control mixtures (Table 1) were prepared to treat all the hives.

Table 1: Treatment preparations

\begin{tabular}{|l|l|}
\hline Neem oil, (N) & $\begin{array}{l}\text { prepared by mixing } 30 \mathrm{ml} \text { oil with canola oil (approximately } 83 \mathrm{ml} \text { ) } \\
\text { to obtain } 200 \mathrm{ml} \text { of solution. }\end{array}$ \\
\hline Amitraz (A) & $\begin{array}{l}\text { prepared by mixing } 12.5 \mathrm{ml} \text { of } 6.25 \% \text { amitraz with canola oil } \\
\text { (approximately } 187.5 \mathrm{ml} \text { ) to obtain } 200 \mathrm{ml} \text { of solution. }\end{array}$ \\
\hline $\begin{array}{l}\text { Neem oil and } \\
\begin{array}{l}\text { Amitraz } \\
\text { mixture (NA) }\end{array}\end{array}$ & $\begin{array}{l}\text { prepared by mixing } 30 \mathrm{ml} \text { oil with } 12.5 \mathrm{ml} \text { of amitraz canola oil } \\
\text { (approximately } 157.5 \mathrm{ml} \text { ) to obtain } 200 \mathrm{ml} \text { of solution. }\end{array}$ \\
\hline
\end{tabular}




\section{Treatment Procedure}

The treatment procedure was adapted from Allam et al. (2003), where each experimental colony is treated once by placing one strip of thick cotton paper towel (13 in by $5 \mathrm{in}$, folded once) saturated with oils $(15 \mathrm{ml})$ from the respective solutions. The strip was placed on the top center of the brood box and remained during the treatment period of 5 weeks. The treatments were prepared with canola oil as an additive.

After 5 weeks, sampling was repeated for all the hives. Based on the observed results from the initial treatment, each hive was treated with the NA mixtures. Since the NA mixture was the strongest of the treatments, it was an efficient means to determine the true effectiveness of each of the treatments. By treating with the NA mixtures, the mites that did not die during the first treatments would be captured by this second treatment and therefore, the more mites captured the second time, the less effective the initial treatment was.

It is important to note that statistical analysis could not be determined in this second phase since the untreated hives could not remain untreated for the five weeks and had to be treated two weeks after the initial treatment. This was because of the loss of two hives that died. Since each hive is worth $\$ 3000$ for a yearly production, the beekeeper did not want to risk losing more hives by not treating them and therefore each untreated hive was treated with one of the treatments by random selection. 


\section{Sampling Procedure}

\section{Materials}

The materials used in this experiment included: quart mason jar w/ modified lid (8 mesh screen), powdered sugar, tablespoon; white [mite] counting dish; cooking spray, white cardboard, measuring cup (1/4 cup); beekeeping tools (hive tool, tweezers, smoker), and beekeeping suit and veil.

\section{Queen fecundity to measure colony strength}

Queens play a vital role in the overall inclusive fitness of all colony members and honey production (Corniffe 2010; Tarpy and Guilley 2004). Through pheromone releases and egg laying patterns, a queen can guide her colony to thrive, starve, or absconding of the hive. The brood area was observed to determine colony strength by observing queen's fecundity. Excellent queens (E) were those whose egg laying pattern took up greater than $85 \%$ of frame area; Good queens (G) lay eggs between 65-85\%; Fair queens (F) between $40-65 \%$, and Poor queens (P) lay eggs in less than $40 \%$ of frame surface area.

\section{Measurement of mite levels}

Many small scale beekeepers usually observe colonies for mite infestation levels before determining treatment options. In order to measure the level of mites in the colonies, samples were taken by adapting the Allam et al. (2003) method. While more mites can be found in cells during the summer months, in the fall/winter more mites are found on the live bees. However, Miami's warm climate allows for year-long brood rearing and therefore mites can be found in both groups. Therefore, although this method was tedious, it provides an adequate representation of infestation levels for different colony groups in addition to fallen mites due to the treatment. Treatment was selected for 
the month of December where brood rearing was expected to be lower and more mites could be found on adult bees. The infestation levels were determined before treatment, and at 5 weeks of treatment. The following data was recorded: number of live mites found in $~ 70$ live bees; number of mites in 10 cells worker and drone brood or in 20 worker cells if drone not available; and number of dead mites fallen during treatment.

Measuring the number of live mites found in $\sim 70$ live bees provides a good indication of adult mite infestation. In order to collect the samples, first the colony was opened to the brood cluster and one or more frames were selected and observed for brood production. The bees were shaken from $1-3$ brood frames into a 5 gallon bucket and $1 / 4$ cup of bees were scooped and transferred into a mason jar, quickly covering with a lid. After collecting all the samples, 1-2 heaping tablespoons of powdered sugar were added to the bees in the sample jar. The jar was shaken vigorously for 1-2 minutes to distribute the powdered sugar over the bees - if bees were not covered, more sugar was added. The jar was inverted over a white dish and vigorously shaken and tapped to remove the mites and sugar from jar. This was repeated about three times or until no more mites were observed. The numbers of mites obtained were then recorded and the bees were then released. Dr. Caron from the University of Delaware, and others have found this method more effective, removing about $90 \%$ of live mites, when compared to the traditional ethanol procedure that removes about $50 \%$ and destroys live bee samples (Schuler, NJDA).

In order to obtain adequate infestation levels, samples of mites in brood were needed. The number of mites in 10 cells worker and drone brood or in 20 worker cells (if drone not available) were obtained for each hive before treatment and at 5 weeks of 
treatment. To obtain these mites, first the colony was opened to the brood cluster and one or more frames were randomly selected. Then the cells were uncapped using tweezers and the developing brood/drone was removed and placed on a petri dish for observation of mites. The mites were then summed for each hive.

In order to measure the effectiveness of the treatments, dead mites were collected three days after treatment. This was done by placing a white cardboard coated with cooking spray underneath the colony. Sometimes, a machete was used to break up hard wax under the hive. After three days of treatment, the cardboard was carefully removed and the number of dead/morbid mites was counted.

\section{Honey yield}

It is known that there is a strong correlation between a colony's strength and food supply, and honey yield provides a good indication of this relationship (Jevtic et al. 2009). By measuring the total honey yield from each colony, we can determine whether the sites had any influence on colony strength and whether the treatments had any long term effects. The [almost] empty honey supers were weighed in early January (after the treatment period). After five months the honey was ready to be harvested, so the weight of the full supers was estimated based on type of super and known full weight of super.

\section{Assessment of the efficacy levels}

Similar to Allam et al. (2003), Girdani \& Leporati (1989)'s equation was also used to test the efficacy of the tested essential oil mixtures:

$$
\text { Rate of efficacy } \%=\frac{\text { No. of dead mites } *}{\text { Total No. of mites } * *} \times 100
$$

* Dropped mites due to treatment + natural mortality

** Dropped mites + no. of mites on $\sim 70$ live bees + no. of mites in 10 (or 20 ) brood cells 
Statistical analysis was determined using one-way ANOVA with a completely randomized design. Generalized linear models were used because it allowed for nesting of site and type of site (i.e., conventional vs. organic). A Bonferroni test was used to compare different treatments to the untreated. A Shapiro-Wilk test was used to test for normality. A maximum likelihood estimator was used to control for pre-treatment mite samples within the population. Chi-square tests were used to demonstrate difference in queen fecundity change between the treatments and sites. One-way ANOVAs were used to determine differences in honey weight for each site. Moreover, after the treatment period of five weeks, all the hives were treated with the NA treatment to determine whether the treatments were effective at capturing all the mites. Statistical analysis could not be used because the untreated hives were treated during the 5 week treatment period as a precautionary measure; therefore, qualitative observations were made. 


\section{Results}

\section{Assessment of the efficacy levels}

The Girdani \& Leporati assessment of the efficacy levels demonstrates the Neem and Amitraz (NA) mixture to be most effective at controlling mite levels. To obtain the rate of effectiveness at each site, the equation used the total number of dead mites on the sticky board in the untreated hives of each site as natural mortality (see table 2). In addition, data for each treatment type was totaled for each farm site. The average rate was then calculated for each treatment type. Although the natural mortality of each site was used, the untreated hives had an average mite mortality of $15 \%$. Two of the untreated hives in $\mathrm{C} 1$ containing large amounts of mites died. Although mites are usually to blame, for this study we cannot conclude that mites were the primary cause of absconding the hive, or if lack of resource availability, diseases, or Colony Collapse Disorder (CCD) also influenced this phenomenon. As a result of this loss, all untreated hives were treated with one of the treatment variables after data were collected but before the five weeks when the second NA treatment was given.

The neem treatment was the least effective at killing the mites, despite its similarity to amitraz treated hives with respect to pretreatment mite levels. In addition, data for the dead mites on sticky board could not be obtained for $\mathrm{C} 1$ because the bees chewed the sticky board. As a result of board consumption, the average rate of effectiveness for neem was $46 \%$; however not including $\mathrm{C} 1$ increases the effectiveness to $54 \%$. 
Amitraz was more effective than neem at treating mites. With similar mite levels, the amitraz treatment was almost twice as effective as the neem treatments. The average rate of effectiveness for amitraz was $86 \%$. However, $\mathrm{C} 1$ hives also seem to affect the results of the equation because the hives chosen for this treatment had much fewer mites than the untreated, therefore resulting in an efficacy rate of only $10 \%$ at this site. This demonstrates that this equation may not be adequate in all cases and that Amitraz effectiveness was probably higher.

The neem and amitraz mixture was most effective at treating mite levels in all sites. The average rate of efficacy for NA was $96 \%$. Possibly influencing this high effectiveness is the high pretreatment mite levels in O1. Nevertheless, the mixture still has a higher effectiveness than Amitraz (not including $\mathrm{O} 1$ still gives NA an efficacy rate of $93.67 \%$ ). Although two of $\mathrm{O} 1$ hives contained productive queens, without treatment these hives would have not survived the season (Corniffe, personal communication). The high mite mortality in C2 hives treated with NA demonstrates its true effectiveness, giving that very few pretreatment mite levels and exceptionally high mite mortality after treatment. 
Table 2: Rate of efficacy for each site and treatment type

\begin{tabular}{|ccccc|}
\hline & & \multicolumn{3}{c|}{$\begin{array}{c}\text { Dead mites } \\
\text { on sticky } \\
\text { board }\end{array}$} \\
Neem & Mites in brood & Rees & 16 & $50 \%$ \\
O1 & 5 & 6 & - & - \\
C1 & 5 & 8 & 21 & $55 \%$ \\
O2 & 5 & 9 & 30 & $56 \%$ \\
C2 & 7 & 7 & $57^{*}$ & $46 \% *$ \\
\hline
\end{tabular}

*Results not collected due to bees chewing up sticky board

\begin{tabular}{|lcccc|}
\hline & & \multicolumn{3}{c|}{$\begin{array}{l}\text { Dead mites } \\
\text { on sticky } \\
\text { board }\end{array}$} \\
Amitraz & Mites in brood & $\begin{array}{l}\text { Mites in live } \\
\text { bees }\end{array}$ & 126 & $85 \%$ \\
C1 & 2 & 16 & 5 & $10 \%$ \\
O2 & 2 & 0 & 92 & $93 \%$ \\
C2 & 3 & 1 & 187 & $84 \%$ \\
Totals & 9 & 17 & 410 & $86 \%$ \\
\hline
\end{tabular}

\begin{tabular}{|c|c|c|c|c|}
\hline Neem\&Amitraz & Mites in brood & $\begin{array}{l}\text { Mites in live } \\
\text { bees }\end{array}$ & $\begin{array}{l}\text { Dead mites } \\
\text { on sticky } \\
\text { board }\end{array}$ & Rate \\
\hline $\mathrm{O} 1$ & 24 & 66 & 1448 & $94 \%$ \\
\hline $\mathrm{C} 1$ & 3 & 15 & 862 & $93 \%$ \\
\hline $\mathrm{O} 2$ & 4 & 1 & 59 & $88 \%$ \\
\hline $\mathrm{C} 2$ & 5 & 4 & 615 & $97 \%$ \\
\hline Totals & 36 & 86 & 2984 & $96 \%$ \\
\hline
\end{tabular}

\begin{tabular}{|c|c|c|c|c|}
\hline Untreated & Mites in brood & $\begin{array}{l}\text { Mites in live } \\
\text { bees }\end{array}$ & $\begin{array}{l}\text { Dead mites } \\
\text { on sticky } \\
\text { board }\end{array}$ & Rate \\
\hline 01 & 3 & 3 & 5 & $45 \%$ \\
\hline $\mathrm{C} 1$ & 11 & 37 & 43 & $47 \%$ \\
\hline $\mathrm{O} 2$ & 2 & 9 & 3 & $21 \%$ \\
\hline $\mathrm{C} 2$ & 7 & 7 & 9 & $39 \%$ \\
\hline Totals & 23 & 56 & 60 & $38 \%$ \\
\hline
\end{tabular}


A one-way ANOVA was used to determine whether there was a

difference between initial mite infestations for the different sites and

treatments (Table $3 \& 4$ ). Both ANOVAs demonstrated no significant

difference in initial mite levels between types of site or between hives selected

for treatments $(F=1.182, p=0.327$ for the treatment teste; $F=1.712, p=$

0.134) for the site test, which demonstrates randomness in mite levels and

therefore strengthens observed results.

Table 3: Initial mite levels based on treatment type

\begin{tabular}{|l|r|r|r|r|r|}
\hline & Sum of Squares & df & Mean Square & F & Sig. \\
\hline Between Groups & 285.667 & 3 & 95.222 & 1.182 & .327 \\
Within Groups & 3544.000 & 44 & 80.545 & & \\
Total & 3829.667 & 47 & & & \\
\hline
\end{tabular}

Table 4: Initial mite levels based on site type

\begin{tabular}{|l|r|r|r|r|r|}
\hline & Sum of Squares & df & Mean Square & F & Sig. \\
\hline Between Groups & 882.667 & 7 & 126.095 & 1.712 & .134 \\
Within Groups & 2947.000 & 40 & 73.675 & & \\
Total & 3829.667 & 47 & & & \\
\hline
\end{tabular}

A Shapiro-Wilk test demonstrated that the number of dead mites on sticky board had a normal distribution. After running statistical analysis on, only NA treatments were significant when compared to the untreated hives at $\alpha=.05$ (Table 5). A Bonferroni test was used for multiple comparisons and specifically, to compare each treatment to the control group (i.e., untreated). The NA treatment was significantly different from all the other treatments, while Neem, Amitraz, and the Untreated hives were all similar to each other. 
Table 5: Multiple Comparison of dead mites in sticky board (after first treatment)

\begin{tabular}{|c|c|c|c|c|c|c|}
\hline \multirow[b]{2}{*}{ (I) First Treatment } & \multirow[b]{2}{*}{ (J) First Treatment } & \multirow{2}{*}{$\begin{array}{c}\text { Mean } \\
\text { Difference (I- } \\
\text { J) }\end{array}$} & \multirow[b]{2}{*}{$\begin{array}{l}\text { Std. } \\
\text { Error }\end{array}$} & \multirow[b]{2}{*}{ Sig. } & \multicolumn{2}{|c|}{ 95\% Confidence Interval } \\
\hline & & & & & $\begin{array}{l}\text { Lower } \\
\text { Bound }\end{array}$ & $\begin{array}{l}\text { Upper } \\
\text { Bound }\end{array}$ \\
\hline \multirow[t]{4}{*}{ Untreated } & Neem & -.417 & 47.380 & 1.000 & -131.32 & 130.49 \\
\hline & Amitraz & -29.000 & 47.380 & 1.000 & -159.90 & 101.90 \\
\hline & Neem $15 \%$ and & -243.500 & 47.380 & .000 & -374.40 & -112.60 \\
\hline & Amitraz $3.125 \%$ & & & & & \\
\hline \multirow[t]{4}{*}{ Neem } & Untreated & .417 & 47.380 & 1.000 & -130.49 & 131.32 \\
\hline & Amitraz & -28.583 & 47.380 & 1.000 & -159.49 & 102.32 \\
\hline & Neem $15 \%$ and & $-243.083^{*}$ & 47.380 & .000 & -373.99 & -112.18 \\
\hline & Amitraz $3.125 \%$ & & & & & \\
\hline \multirow[t]{4}{*}{ Amitraz } & Untreated & 29.000 & 47.380 & 1.000 & -101.90 & 159.90 \\
\hline & Neem & 28.583 & 47.380 & 1.000 & -102.32 & 159.49 \\
\hline & Neem $15 \%$ and & $-214.500^{*}$ & 47.380 & .000 & -345.40 & -83.60 \\
\hline & Amitraz $3.125 \%$ & & & & & \\
\hline \multirow{3}{*}{$\begin{array}{l}\text { Neem } 15 \% \text { and } \\
\text { Amitraz } 3.125 \%\end{array}$} & Untreated & $243.500^{*}$ & 47.380 & .000 & 112.60 & 374.40 \\
\hline & Neem & $243.083^{*}$ & 47.380 & .000 & 112.18 & 373.99 \\
\hline & Amitraz & $214.500^{*}$ & 47.380 & .000 & 83.60 & 345.40 \\
\hline
\end{tabular}

The multiple factors present in the design, such as the nestedness of treatment types within the type of site and the use of sampling data, required closer observation. Therefore, several modifications were made to the ANOVA to confirm the results obtained and to see if there were any differences among the type of site and treatments. In order to understand whether the type of site had any impact on treatment effectiveness, a generalized linear model was used to control for nestedness of treatment variables within the type of site (Table 6).By grouping the types of sites together, we were able to see that the all the treatments were slightly more effective in the organic sites, with NA showing 
the highest difference in effectiveness ( $B=7.373$ for [NA] (conventional) and $B=14.035$ [NA] (Organic)). Also, a maximum likelihood estimator was used to control for pretreatment mite samples within the population. The normality test was skewed at first, but after a transformation of the square-root, the Akaike Information Criteria was lowered and therefore mite mortality results became more normal. The Bonferroni test demonstrated that mite mortality was not different among sites. The similar $p$ values for each treatment indicates that the site does not impact the effectiveness of the treatment applied. Analysis of the multiple comparison of each of the treatment to the untreated at both organic sites and conventional sites showed that both NA and A treatments were significantly different from the untreated in both organic sites and conventional sites. Amitraz treatments probably became significant because the sample size increased by 3 colonies when the type of sites were combined. Still, the NA treated group was about 1.5

Table 6: Comparison of treatments to untreated for organic and conventional sites

\begin{tabular}{|c|c|c|c|c|c|c|c|}
\hline \multirow[b]{2}{*}{ Parameter } & \multirow[b]{2}{*}{ B } & \multirow{2}{*}{$\begin{array}{l}\text { Std. } \\
\text { Error }\end{array}$} & \multicolumn{2}{|c|}{ 95\% Wald Confidence Interval } & \multicolumn{3}{|c|}{ Hypothesis Test } \\
\hline & & & Lower & Upper & Wald Chi-Square & df & Sig. \\
\hline [NA] (conventional) & 7.373 & 1.8869 & 3.675 & 11.072 & 15.269 & 1 & .000 \\
\hline [A] (conventional ) & 4.113 & 1.7002 & .780 & 7.445 & 5.851 & 1 & .016 \\
\hline [N] (conventional) & 1.010 & 1.7172 & -2.356 & 4.375 & .346 & 1 & .557 \\
\hline [Untreated] (conventional) & $0^{\mathrm{a}}$ & & & & & & \\
\hline [NA] (Organic) & 14.035 & 1.7400 & 10.624 & 17.445 & 65.060 & 1 & .000 \\
\hline [A] (Organic) & 4.518 & 1.7492 & 1.090 & 7.946 & 6.672 & 1 & .010 \\
\hline [N] (Organic) & 1.838 & 1.7495 & -1.591 & 5.267 & 1.104 & 1 & .293 \\
\hline [Untreated] (Organic) & & & & & & & \\
\hline (Scale) & $8.635^{\mathrm{b}}$ & 1.7627 & 5.788 & 12.884 & & & \\
\hline
\end{tabular}
a. Set to zero because this parameter is redundant.
b. Maximum likelihood estimate. 
times more effective at treating mites. This was evident from the coefficient $B$ which demonstrates this ratio.

In order to determine true effectiveness of the treatments, all hives were treated with NA after 5 weeks of the initial treatments. Statistical analysis could not be calculated because of the loss of the untreated group. However, results from the second dosage of NA demonstrated Neem to be least effective (Figure 2). Mite count was higher for neem treated groups, indicating that initial (Neem) treatment was not effective and mite levels were increasing during the five weeks. Mite levels were controlled in both the Amitraz and NA groups.

Figure 3: Count of mite mortality after different treatments

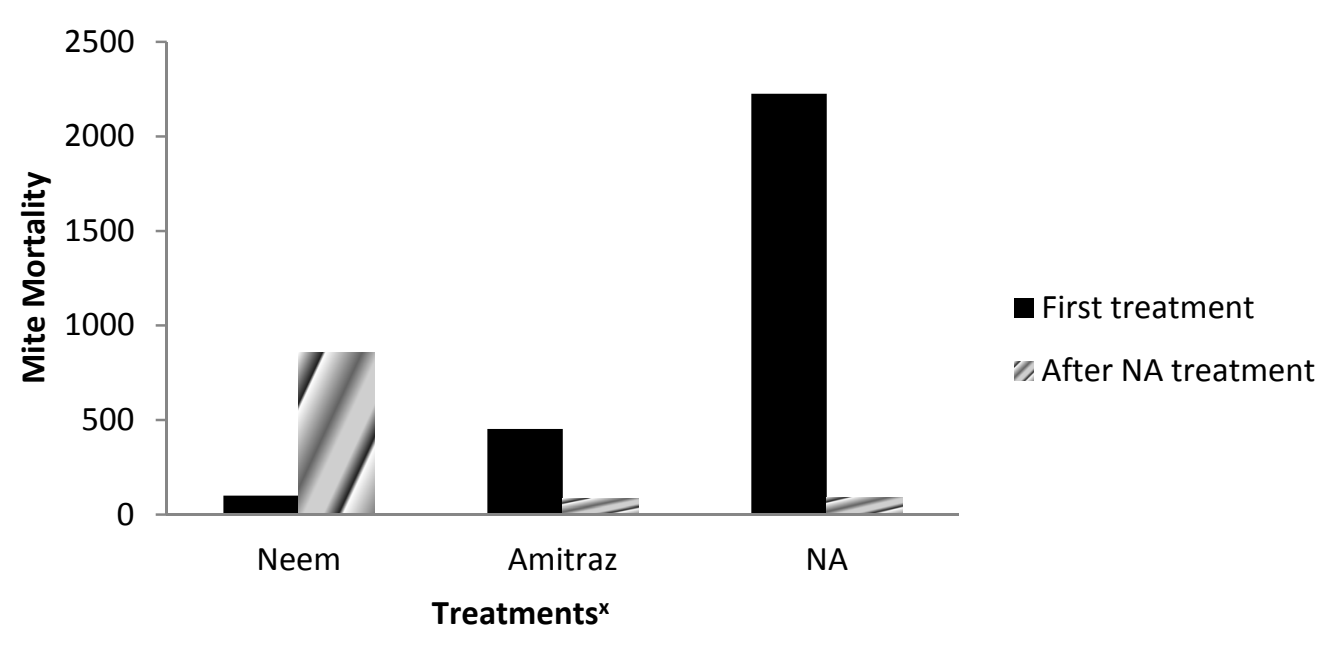

${ }^{x}$ Counts do not include $\mathrm{C} 1$ due to torn sticky board

Queen fecundity can provide information about the queen's fertility, colony strength, and possible treatment impacts. Northern states usually experience a decrease in egg laying pattern during the winter months as a result of cold temperature and reduced flower availability, and highest egg laying pattern during the summer. Although there 
was a cold front present during initial treatment measurements, the queens were still producing new brood (Figure 3). The initial estimates showed that queen fecundity was lowest in $\mathrm{O} 1$ and very similar in $\mathrm{C} 1, \mathrm{O} 2$, and $\mathrm{C} 2$. When queen fecundity was measured after five weeks, the temperature was warmer. As expected, there was an increase in the total number of Excellent queens and a reduction in Fair and Poor queens (Figure 5). Queen fecundity increased in all the sites except $\mathrm{C} 1$, with $\mathrm{C} 2$ having the highest increase (Figure 3). Per treatment type, there was an increase in the mean value of queen fecundity in Neem and Amitraz treated groups, while a decrease in the untreated group (because of the loss of two hives); no change was observed in the NA group (Figure 4). Chi-square tests demonstrated no difference in queen fecundity change between the treatments or sites. There was only a significant difference in queen fecundity change between $\mathrm{C} 1$ and $\mathrm{O} 2$. This was because of $\mathrm{C} 1$ losing two hives and $\mathrm{O} 2$ showing improvement in queen fecundity for all hives. Seven of the 48 hives experienced a decrease in queen fecundity, four of which were in $\mathrm{C} 1$. Mites and poorly mated queens were the reasoning behind five of the seven hives. Reasoning behind this reduction was not evident for C1N1, and C2NA2; but both produced low and high honey yields respectively, thereby indicating a possible relationship between colony health and site. 
Figure 4: Mean value of queen fecundity before and after treatment period at each site A. Mean queen fecundity before treatment. B. Mean queen fecundity after treatment. C. Mean change in queen production.

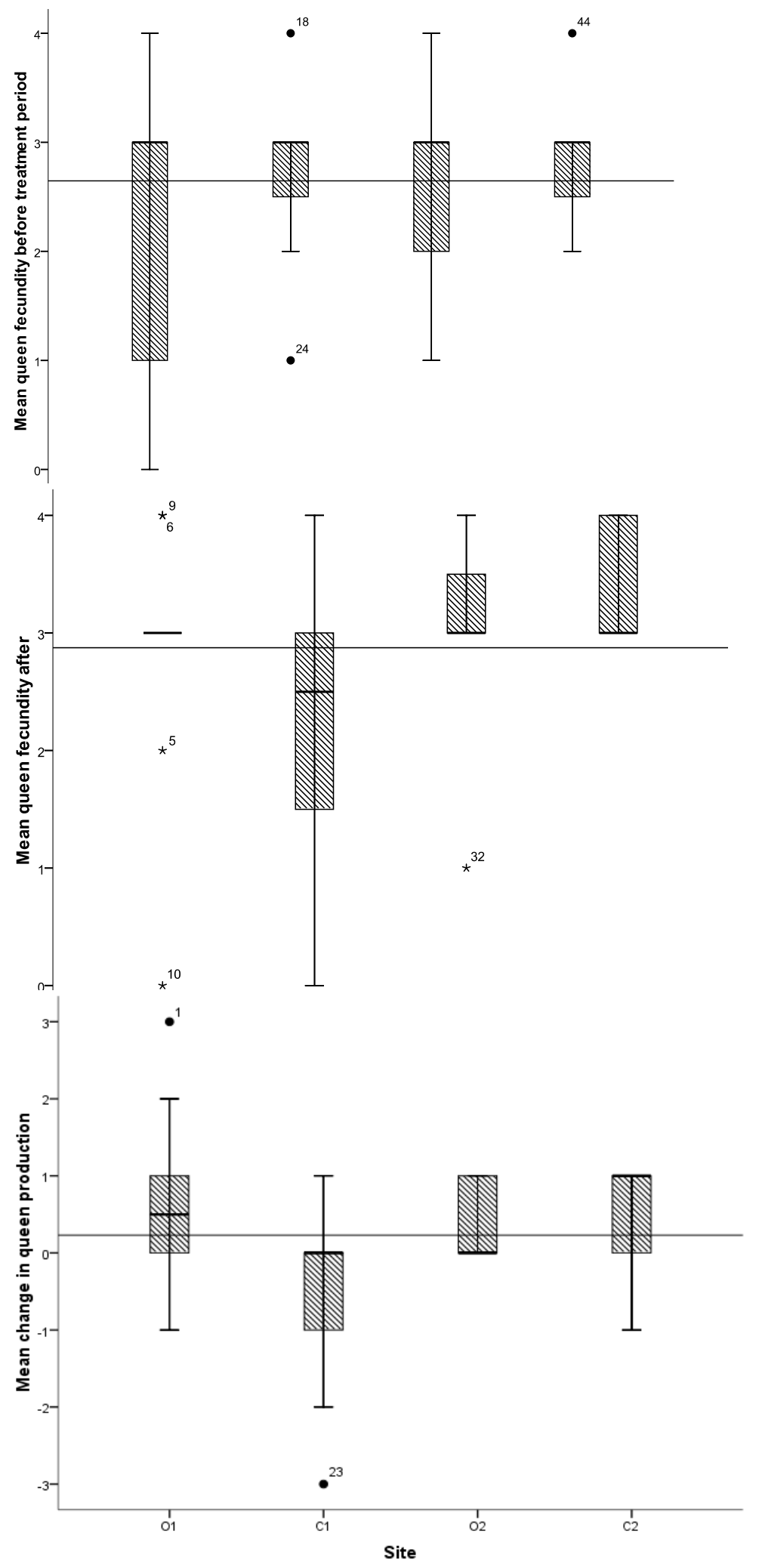


Figure 5: Mean value of queen fecundity before treatment and after five weeks of treatment

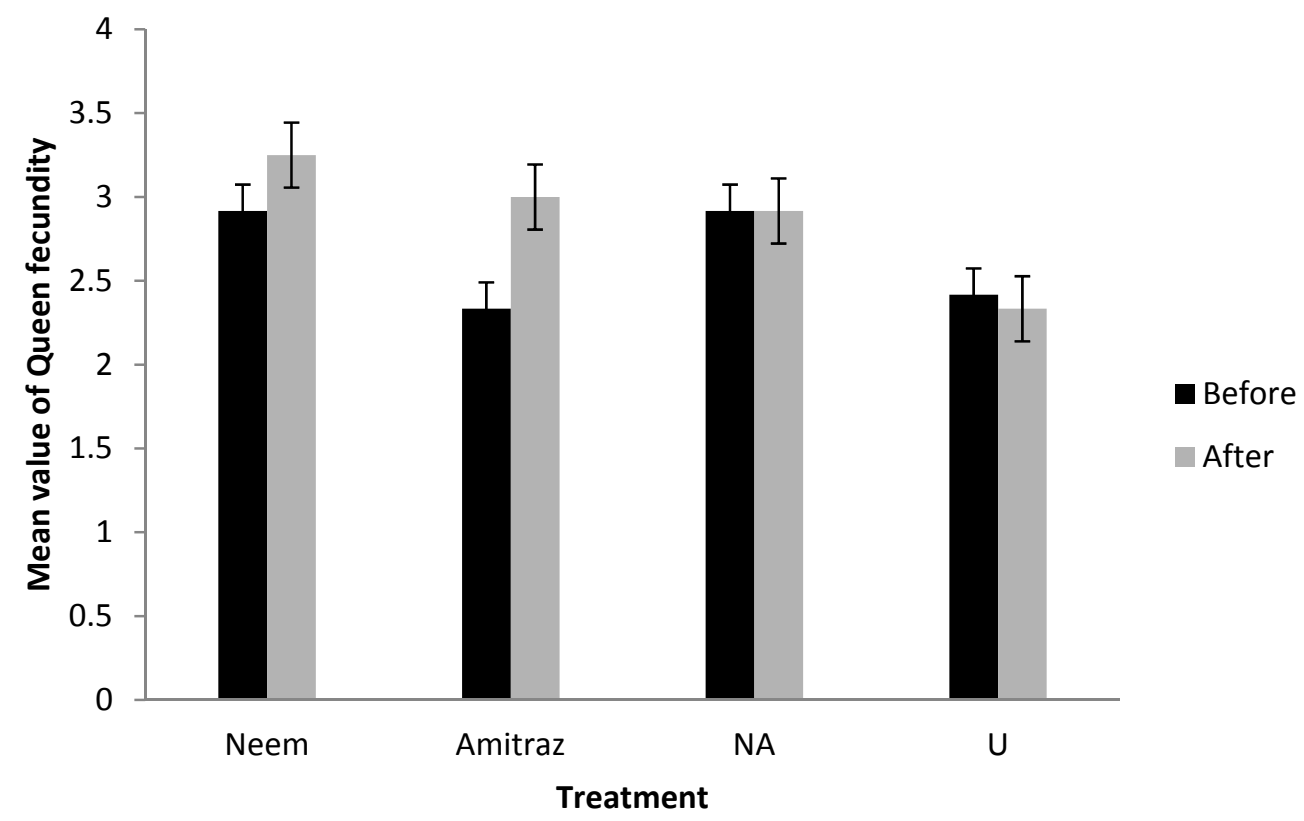

Figure 6: Total count of queen fecundity before and after treatment period

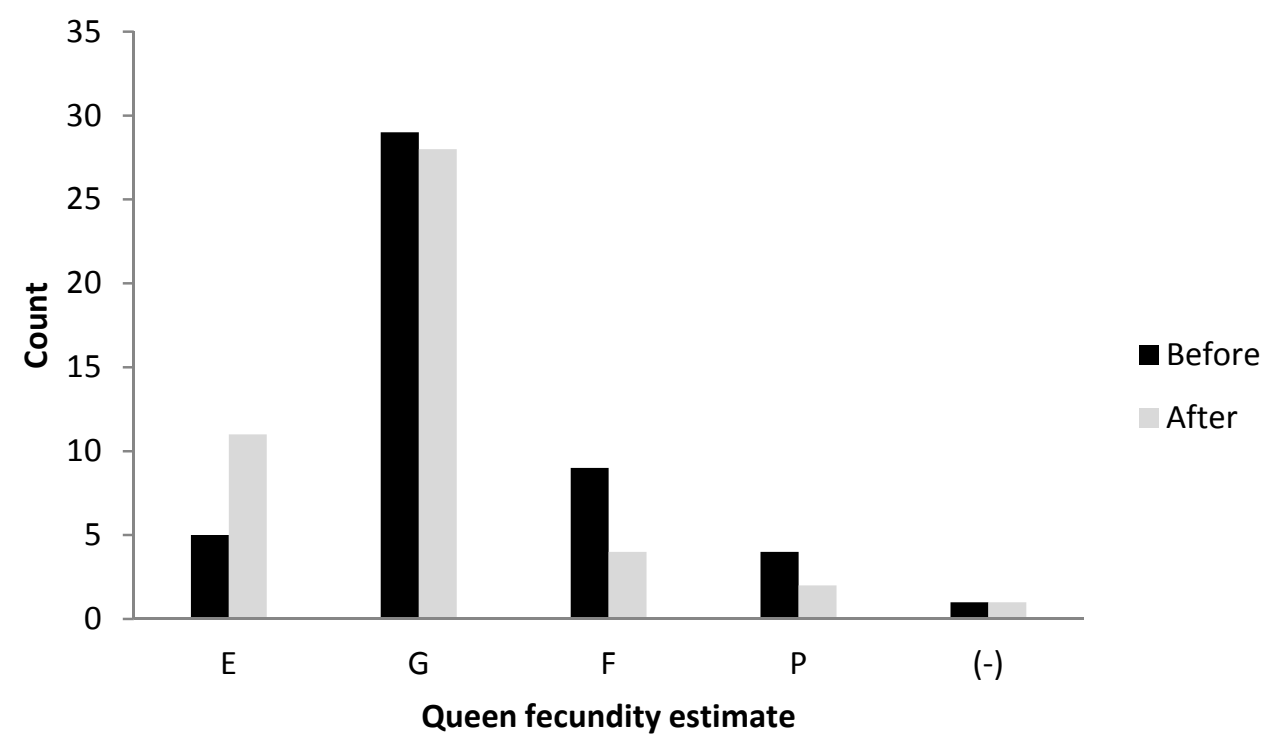


Table 7: Chi-Square Test demonstrating difference between $\mathrm{C} 1$ and $\mathrm{O} 3$ in queen fecundity change

\begin{tabular}{|c|c|c|c|c|c|}
\hline & Value & df & $\begin{array}{l}\text { Asymp. Sig. (2- } \\
\text { sided) }\end{array}$ & $\begin{array}{l}\text { Exact Sig. (2- } \\
\text { sided) }\end{array}$ & $\begin{array}{l}\text { Exact Sig. (1- } \\
\text { sided) }\end{array}$ \\
\hline Pearson Chi-Square & $4.800^{a}$ & 1 & .028 & \multirow{6}{*}{.093} & \multirow{6}{*}{.047} \\
\hline Continuity Correction ${ }^{\mathrm{b}}$ & 2.700 & 1 & .100 & & \\
\hline Likelihood Ratio & 6.351 & 1 & .012 & & \\
\hline Fisher's Exact Test & & & & & \\
\hline Linear-by-Linear Association & 4.600 & 1 & .032 & & \\
\hline $\mathrm{N}$ of Valid Cases & 24 & & & & \\
\hline
\end{tabular}

Figure 7: Chi-square test showing difference in queen fecundity based on site

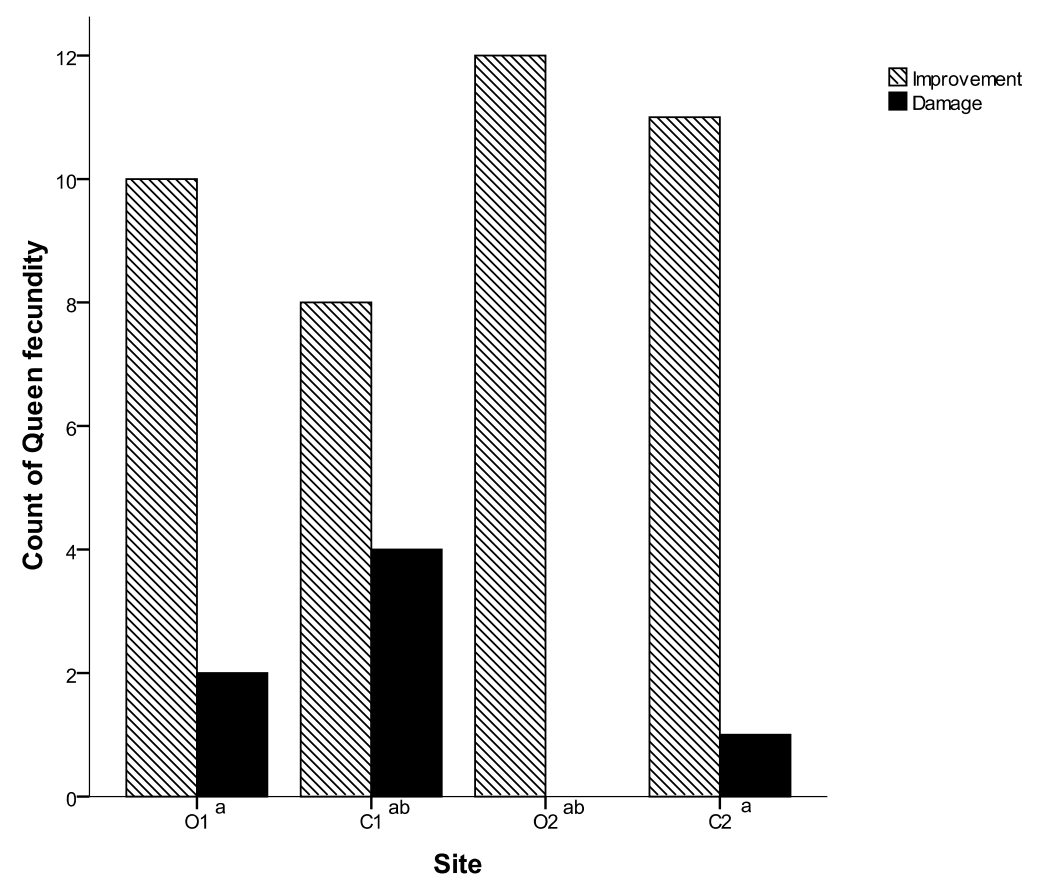




\section{Honey yield}

Honey yield can provide a good measurement of food availability, thereby demonstrating colony strength (Jevtic 2009). Weight of initial honey yield was taken by weighing the supers after the treatment period (January), while final weight (after five months) was taken by estimating known weight of full supers derived from the size of supers and assuming the super was full. During initial observations, there was a much higher incidence of honey robbing in $\mathrm{C} 1$ than the other sites. The hives in $\mathrm{O} 2$ and $\mathrm{C} 2$ were placed in their location two months before the experiment, while $\mathrm{O} 1$ and $\mathrm{C} 1$ hives were placed only one month before beginning the experiment. Naturally, we expected $\mathrm{O} 2$ and $\mathrm{C} 2$ to have more winter honey stores than $\mathrm{O} 1$ and $\mathrm{C} 1$ (Figure 7). However, both organic sites had significantly higher honey yield before and after five month (when the honey was ready to be harvested) than $\mathrm{C} 1$. In addition, although $\mathrm{C} 2$ was not different from the organic sites, it was also not different from $\mathrm{C} 1$. While $\mathrm{C} 2$ is a conventional site, it is situated within the Homestead growing area with a diversity of nearby flower sources. The larger flower availability and better protection from frost allowed for better preparedness for winter and may have reduced treatment impacts. 
Figure 8: Total honey yield before treatment and after season (5 months)

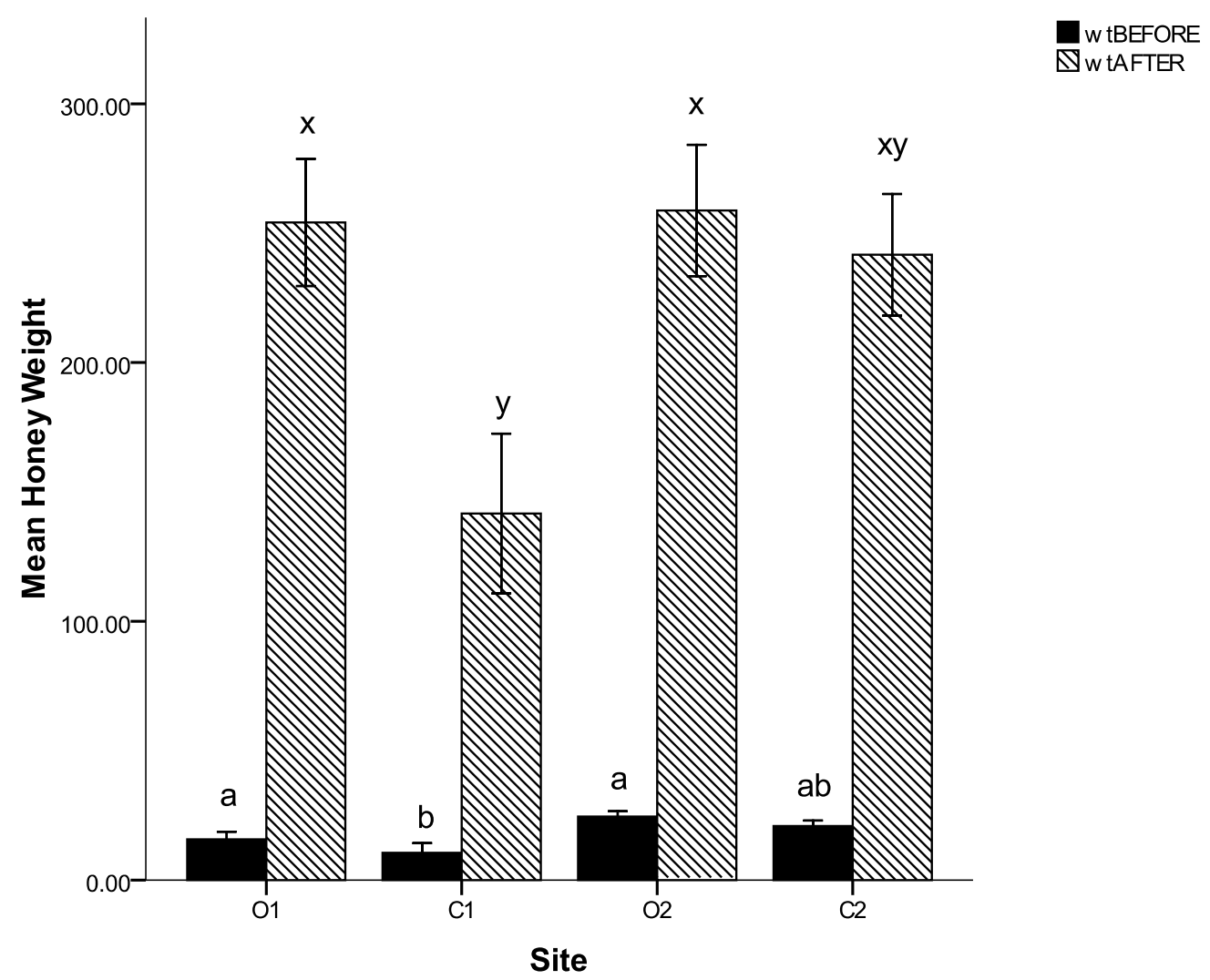

While O1 contained less honey than C2 initially, final honey harvest was higher. Therefore, further analysis was done to determine differences in improvement of honey weight for each site. The results demonstrated that $\mathrm{O} 1$ had the highest improvement; however, it was not different from $\mathrm{O} 2$ and $\mathrm{C} 2$ (Figure 8). Site $\mathrm{C} 1$ demonstrated the least improvement. The data coincides with visual observation of flower availability around each site. 
Figure 9: Improvement in honey weight for each site

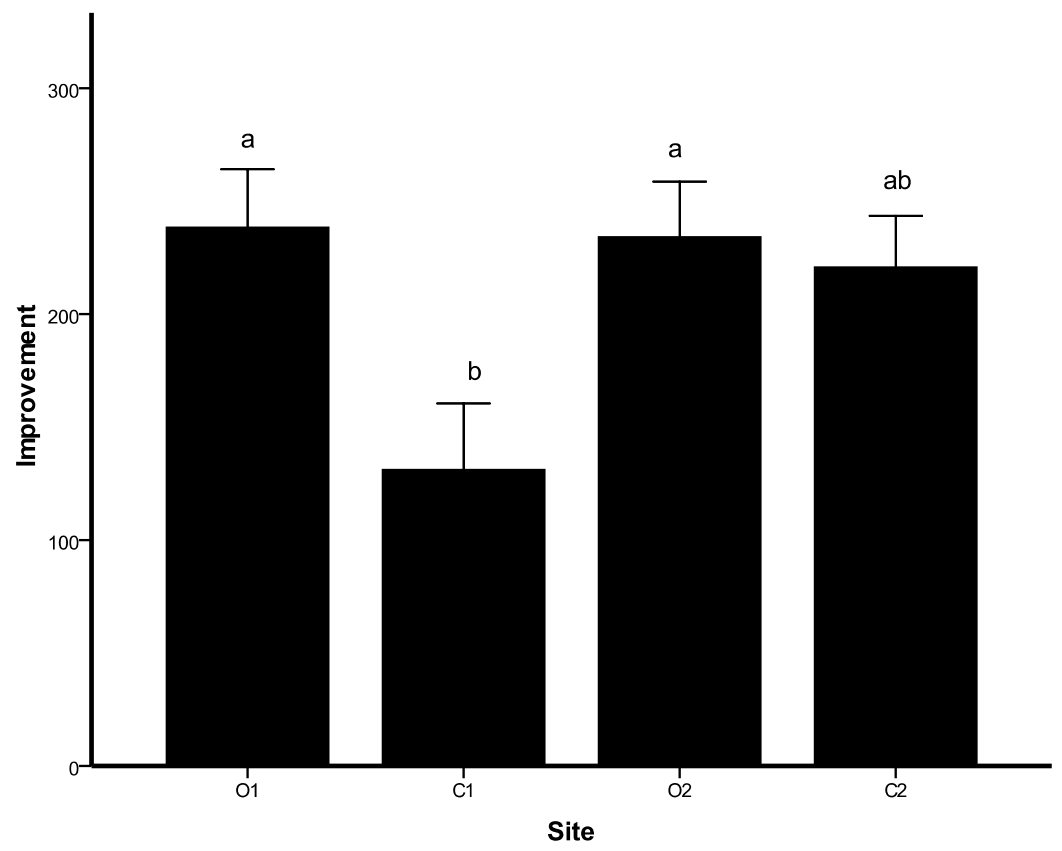

Table 8: One-way ANOVA demonstrating differences in improvement of honey by each site

\begin{tabular}{|l|r|r|r|r|r|}
\hline & Sum of Squares & df & Mean Square & \multicolumn{1}{|c|}{$\mathrm{F}$} & \multicolumn{1}{c|}{ Sig. } \\
\hline Between Groups & 92030.277 & 3 & 30676.759 & 3.872 & .015 \\
Within Groups & 348586.373 & 44 & 7922.418 & & \\
Total & 440616.650 & 47 & & & \\
\hline
\end{tabular}




\section{Discussion}

\section{Treatment Effectiveness}

On the basis of the results, neem oil alone is not an effective alternative to synthetic acaricides at controlling mite levels. In addition, aggressive chewing behavior was noticed in the three neem treated hives in $\mathrm{C} 1$. One possible explanation for this could be that the neem treated hives contain hygienic genes, which was somewhat noticed from the cleanliness of the hive. The behavior may have also been provoked by food source availability, observed by the flower abundance and subsequent low honey stores at this site, which may have provoked starvation behavior. It could also indicate that neem causes agitation in the bees. Earlier studies indicated neem to be somewhat effective at controlling mite levels with some negative impacts on queen survival and developing brood (Melathopoulos et al. 2000; Mordue and Blackwell 1993; Naumann and Isman 1996, Rembold et al. 1980). Other studies have shown no effects on bee development, adult bee, or Varroa control (Bunsen J. 1991). The contradicting findings indicate the need for further research on toxic components of neem, which may differ based on cultivation growing climatic conditions, and extraction. Azadirachtin, a component of neem, is thought to affect bee brood without impacting Varroa (Schenk 2001). It is difficult to assess whether our $15 \%$ neem treatment contained azadirachtin since the experiment demonstrated no significant difference in mite control between not treating and treating with neem, yet no long term impact was observed on queen fecundity and developing brood when treating with neem. However, short term impacts on developing brood was not recorded because of cold fronts experienced during treatment period, so 
impact on brood cannot be concluded with full confidence. Nevertheless, brood rearing increased in all of the neem treated hives, with $\mathrm{C} 1 \mathrm{~N} 1$ being the exception. Combination of neem and other essential oils or natural substances may increase its effectiveness against Varroa and should be further researched.

Amitraz proved to be a better acaricide with no noticed long term effect on colony strength as well. When sample size included all the colonies and variables, amitraz became significantly different from the untreated in treatment effectiveness (table 6). Research has indicated mite resistance to amitraz in Minnesota and other areas (Elzen et al. 2000; Milani 1999). However, on the basis of the results of this study, we can conclude that mites in South Florida are not resistant to amitraz, but are showing signs of increased tolerance ${ }^{1}$. While concerns on amitraz impact to honey bees is still reasonably prevalent, this study demonstrated no long term impact to queen fecundity (Figure 4). All hives treated with amitraz experienced improvement in brood rearing after five weeks of treatment. A possible likelihood to this finding is that these hives were probably treated with amitraz previously. Therefore, although amitraz was effectiveness, it should still remain as a last resort, reactive approach.

As hypothesized, NA treatments were most effective at combating mite levels. However, there was no long term difference in mite control between A and NA treated groups. Lower pre-treatment mite levels in A treated groups could be the reasoning behind this lack of long term difference. The NA treated groups did have a higher pretreatment mite levels, although this difference was not significant. If A treated colonies contained a higher amount of mite infestation initially, the treatment might have shown a higher level of effectiveness. There was also no long term impact on queen fecundity in ${ }^{1}$ Since Fluvinate resistance in Florida began, beekeepers in Florida have been slowly increasing their use of Amitraz to combat mites. 
NA treated hives (Figure 4).Three of the hives treated with NA experienced reduced queen fecundity after five weeks, while four improved and five remained equal in terms of fecundity. It was confirmed that poor mating was the reasoning in reduced brood rearing for one of these hives (C1NA2). Hives O1NA1, O1NA2, and C1U2 contained the most mites and although the queens in these hives were all good, mite persistence would have resulted in reduced colony strength or mortality (as was the case with C1U2). The large honey yield in both O1NA1 and O1NA2 indicated that NA treatments did not impact long term colony strength and may have actually improved it. Further studies should consider taking lower dosage of this mixture as a possible therapeutic last resort treatment.

\section{Implications on queen fecundity}

As previously mentioned, several studies have shown possible impacts of both neem and amitraz to brood rearing, but this study demonstrated no long term impact on queen fecundity. Overall, queen fecundity improved in all treatment types except the untreated group (Figure 4), and there was an increase in total number of excellent queens, with a decrease in poor, fair, and good queens, which also indicated overall improved brood rearing (Figure 5). Moreover, all the sites showed increase in queen fecundity with the exception of $\mathrm{C} 1$ (Figure 3). The significant difference between queen fecundity in the conventional monoculture farm located closer to a residential area $(\mathrm{C} 1)$ versus the organic, highly diverse farm surrounded by other farms and natural habitat (O2) demonstrates a possible link between queen fecundity and flower availability. With ample resources and protection from the cold, the queens in cites $\mathrm{O} 1, \mathrm{O} 2$, and $\mathrm{C} 2$ were 
able to continue brood production during the short Florida winter season. On the other hand, short resource availability and possibly, lack of protection from the frost in $\mathrm{C} 1$, may have influenced the reduced brood production. Furthermore, these multiple factors, along with mite infestation and lack of treatment, may have led to the dying of C1U2 and C1U3. The observations and results imply that long term effect of brood rearing is more dependent on proper mating of queens, and resource availability and/or temperature may also play a significant role.

\section{Differences in agricultural management and honey production}

This experiment examined a practical approach to treating mites. The random selection of hives with various mite levels, as well as the method of treatment application, was designed to be applicable to common practices of large scale beekeepers. Some large scale beekeepers treat all of their hives because of the time consuming nature of checking for mite levels, and to reduce the spread of mites between colonies. Other beekeepers take an integrated pest management (IPM) approach by taking samples in order to determine the necessary treatment measures. The latter approach should be the preferred method but requires more observation and understanding of natural control measures.

One aspect is to consider the sites where their bees are situated. If the agroecosystem is organic and diverse in flower abundance and diversity, there may be natural elements that act as preventative strengths which can keep these pests within acceptable bounds (Lewis et al. 1997). Particularly, diversity in flower sources can provide necessary nutrients to increase colony strength. A study in Michigan State University shows that transportation can have a negative impact on honey bee 
development and that lack of pollen nutrition affects longevity more so than infections of Nosema ceranae (Huang 2008). In addition to these stresses, many beekeepers feed supplements to their honeybees in the form of sucrose and high fructose corn syrup because of the limited flowering time and diversity found in monocultures, which leads to a poor diet. While chemically similar, the implication of feeding these sugars on bee behavior is poorly studied. Huang's study also indicated that worker bees fed corn syrup experienced significant negative impacts on their longevity. Another study produced by Huang also demonstrated that nutrition affects long-term behavior patterns and foraging efficiency, which was also observed in C1 (Schulz et al. 1998).

Although the organic sites demonstrate higher colony strength than $\mathrm{C} 2$ in terms of honey yield, the role of pesticide and colony strength could not be assessed in this study. Additional research is needed to better understand the relationship between organic and conventional management and colony strength as the sites in this study are quite small compared to other farms in other states. Sites $\mathrm{O} 1, \mathrm{O} 2$, and $\mathrm{C} 2$, which all contained higher flower abundance and diversity than $\mathrm{C} 1$, produced similar honey yield, with $\mathrm{O} 1$ and $\mathrm{O} 2$ producing significantly higher amount of honey than $\mathrm{C} 1$. Although $\mathrm{C} 2$ was not significantly different from the organic sites, it was also not different from C1. My study does indicate that farms with multiple crops and sustainable practices can improve the resilience of pollinator survivorship by providing abundance resources. For example, both O1NA2 ${ }^{1}$ and $\mathrm{C} 1 \mathrm{U}^{2}$ contained good brood rearing patterns and similarly high level of mites, yet C1U2 died while O1NA2 produced one of the highest honey yields, demonstrating the multiple factors affecting long term colony strength. Although honey production was highest in both organic farms, the results demonstrated that sites with

${ }^{1}$ O1NA2 was in a resource abundant site and treated

${ }^{2} \mathrm{C} 1 \mathrm{U} 2$ was in a resource limited site and was not treated 
highest resource availability and/or abundance play a stronger role than the type of site in colony strength.

In addition, medicating your bees as a protective measure can actually diminish the effectiveness of medication when you absolutely, positively need it. Also, the mites can build a resistance when medications are used too frequently. While it would have been interesting to measure this effect in our untreated colonies, concerns by the beekeeper that more hives would die forced treatment when samples still indicated low mite levels in these colonies. This indicates a need for beekeepers to shift from their practices from a reactive approach to proactive measures and not treat unless necessary. While this approach is sustainable in the long run, it may not be practical at the moment for some colonies and transition may be necessary. When conventional farms turn organic, there is a period of withdraw and time is required for the system to develop inherent strengths to reach stability. Similarly, if treatments are ceased completely, some colonies may not contain the inherent strengths to fight the mites and related diseases. A combination of stable environments, along with transitioning treatments may allow the colonies to build up sufficient strength while still controlling mite levels. Therefore, beekeepers already using Amitraz could try supplementing with essential oil mixtures to wean off this chemical and should place their hives in nutrient diverse, stable environments. This combination of proactive and reactive approaches can lead to improved wellbeing of colonies and sustainable management of mites. 


\section{Conclusion}

Controlling mite levels in colonies is imperative to improving the well being of honey bees. While essential oils have been demonstrated to be effective measures in the past, this study demonstrated neem as an ineffective treatment in colonies that have been previously treated with other acaricides. Using either amitraz or a mixture of neem and amitraz demonstrated control of mite levels over a period of five weeks, with the NA mixture providing the highest effectiveness. Although no long term impact was observed to brood rearing and colony strength, it is still not recommended to use amitraz on colonies. Consequently, beekeepers already using this chemical should consider reducing dosage level of amitraz by mixing with neem or other essential oil in order to slowly reduce applications of this chemical. On the basis of the results of this experiment, where a significant difference in queen fecundity and honey production (demonstrating colony health) was met not by the type of farm but rather the proximity to flower sources and reduced land use change, it can be inferred that flower abundance and/or diversity may play an important role on the wellbeing of the colony. Similar to Kremen et al. (2002), the organic site closest to a natural habitat demonstrated highest honey production and queen fecundity, signifying that land management practices affect pollinator wellbeing. Therefore beekeepers should also take proactive steps to address long term sustainable management of mites by providing stable, flower abundant agroecosystems that can increase their colonies' inherent strengths.

My study adds to the growing body of knowledge by demonstrating that using essential oil/chemical mixtures may be used to control mites when commercially 
available treatments are no longer effective. As the pollinator crisis continues, we must seek proactive approaches for farm and pollinator management. By shifting our paradigm to better understanding the natural process in these systems, we can allow natural regulators to maintain sustainable control of pests and use therapeutic measurements as last resort supports. On the basis of the results, the USDA pollinator protection program should provide monetary incentives to farms that provide large abundance/diversity of flower sources for extended periods of time. In addition, the program's goal will not benefit as much from large farms that practice monoculture. Furthermore, farms with high pesticide application and Bt crop production should be highly evaluated before receiving subsidies for this program due to their known effects on pollinators (Aliouane et al. 2000; Decourtye et al. 2004; Decourtye et al. 2005; Devillers \& Pham-Delegue 2002; Iwasal et al. 2004; Mullin 2010; Schmuck et al. 2001; Villa et al. 2000; Waller et al. 1984). It is important to continue using honeybees in experiments to monitor environmental state and to develop sustainable methods of management so that we may reverse the decline of these ecosystem supporters. 


\section{REFERENCES}

"FAQs related to Varroa Mite". Biosecurity. New Zealand. 30 June 2009. 30 September 2010. Web. http://www.biosecurity.govt.nz/node/1289/related faqs

Acda, Menandro N. 2007. "Toxicity of Thiamethoxam Against Philippine Subterranean Termites." Journal of Insect Science 26 :1-6.

AndersonD. L., Trueman, J. W. H. 2000. Varroa jacobsoni (Acari: Varroidae) is more than one species. Exp. Appl. Acarol. 24:165-189.

Aliouane, Yassine, et al.2000. "Subchronic Exposure of Honeybees to Sublethal Doses of Pesticides: Effects on Behavior." Environmental Toxicology and Chemistry 28.1: 113-22.

Allam, S.F.M.; Hassan, M.F.; Risk, M. A; Zaki, A.U. 2003.Utilization of essential oils and chemical, substances alone or in combination against Varroa mite (Varroa destructor), a parasite of honeybees. Insect Pathogens and Insect Parasitic Nematodes. 26.1: 273-278. Print

Amrine, Jim; Noel, Bob; Mallow, Harry; Stasny, Terry; Skidmore, Robert. 1996. Results of Research: Using Essential Oils for Honey Bee Mite Control. West Virginia University.http://www.wvu.edu/ agexten/ipm/insects/pollinat/varroa/varroa2.htm

Ball, B. 1988. The impact of secondary infections in honey bee colonies infested with the parasitic mite Varroa jacobsoni pp. 457-461. In: Needham G.R., Page, R.E., Delfinado Baker, M., Bownman, C.E., eds. Africanized honey bees and bee mites. Ellis Horwood, Ltd. Chichester, UK. 572 pages.

Barlow, Vonny M. 2009. Sampling Methods for Varroa Mites on the Domesticated Honeybee Department of Entomology, Virginia Tech. http://pubs.ext.vt.edu/444/444-103/444-103.html

Briggs, Shirley. 1992. Basic Guide to Pesticides, Hemisphere Publishing. Washington, DC.

Bunsen, J. 1991. Experimental investigations to combat the mite Varroa jacobsoni: an ectoparasite of the honey bee with materials of natural origin. Dissertation. JustusLiebig-Universitat. Giesen. Germany. Cited in Imdorf (1999) and Schenk (2001). 
Calis, J.N M. Boot, W.J., Beetsma, J. 1999. Model evaluation of methods for Varroa jacobsoni mite control based on trapping in honey bee brood. Apidologie 30: 197207.

Colin M.E. 1990. Essential oils of Labiatae for controlling honey be varroosis. Journal of Applied Entomology. 19-25.

Colin M.E., Garcia Fernandez P., Ben Hamida B. 1999. Varoosis. CIHEAM-IAMZ. p.121-142.

Corniffe, Steve. Personal communication. June 2010-February 2011.

Decourtye, A., et al. 2004 (a). "Imidacloprid Impairs Memory and Brain Metabolism in the Honeybee (Apis Mellifera L.)." Pesticide biochemistry and physiology 78.2: 83-92.

Decourtye, A., et al. 2004 (b). "Effects of Imidacloprid and Deltamethrin on Associative Learning in Honeybees Under Semi-Field and Laboratory Conditions." Ecotoxicology and environmental safety 57.3: 410-9.

Decourtye, A., et al. 2005. "Comparative Sublethal Toxicity of Nine Pesticides on Olfactory Learning Performances of the Honeybee Apis Mellifera." Archives of Environmental Contamination and Toxicology 48.2: 242-50.

Delaplane, K. 1997. Practical science-research. Helping beekeepers: Varroa. Bee World 155-164.

Devillers, James and Pham-Delegue, Minh-ha. 2002 Honey Bees: Estimating the Environmental Impacts of Chemicals. London: Taylor and Francis Inc.

Elzen, Patti, Baxter, James R., Spivak, Marla, and Wilson, William T. 2000. Control of Varroa jacobsoni Oud. resistant to fluvalinate and amitraz using coumaphos Apidologie 31. 437-441.

Frazier, Maryann. "Protecting Honey Bees from Chemical Pesticides." Senior Extension Associate. Penn State. Undated.

Girdani, G. and Leporati, M. "Field trials against Varroa jacobsoni with Apitol.” In: Present status of varroasis in Europe and progress in Varroa Control. Ed. Cavalloro, Meeting of the EX Experts Group/Udine, Italy, 28-30 Nov. 1988. 
Hoppe, H., Ritter, W., Stephen, E.W.C., 1989. The control of parasitic mites: Varroa jacobsoni, Acarapis woodi, and Tropilaelaps clareae with formic acid. Am. Bee J. 129, 739-742.

Hoppe, H (1990). Control of Varroa with a Thermal Treatment in Combination with Wintergreen Oil. Dissertation. Justus Liebig University, Giessen, Germany.

Huang, Z. Y. 2008. "Sustainable Solutions to Problems Affecting Honey Bee Health." USDA: Research, Education \& Economics Information System. Michigan State University (unpublished). http://www.reeis.usda.gov/web/crisprojectpages/212044.html

Huff, Ethan A. 2010. "Bayer pesticide banned over threat to honeybees." Nature News. 22 February 2010. Accessed September 2010. http://www.naturalnews.com/028218 pesticides_honeybees.html

Imdorf, Anton; Bogdanov, Stephen; Ochoa Ibanes, Ruben; and Calderone, Nicolas W. "Use of essential oils for the control of Varroa jacobsoni Oud. in honey bee colonies.” Apidologie 30(1999): 209-228. Print

Iwasal, Takao, et al. 2004. "Mechanism for the differential toxicity of neonicotinoid insecticides in the honey bee, Apis mellifera." Crop Protection 23. 371-378

Jevtić, G., Mladenović, M., Anđelković, B., Nedić, N., Sokolović, D., and Štrbanović, R. 2009. The correlation between colony strength, food supply, and honey yield in honey bee colonies. Biotechnology in Animal Husbandry 25 (5-6), p 1141-1147.

Johnson, Renee (2010). Honey Bee Colony Collapse Disorder. Congressional Research Service: Report for Congress. Technical paper (January 7, 2010)

Kremen, Claire., et al. "Crop pollination from native bees at risk from agricultural intensification.” PNAS .(2002) . vol. 99 . no. 26. 16812-16816

Kidd, H. and James, D. R., Eds. The Agrochemicals Handbook, Third Edition. Royal Society of Chemistry Information Services, Cambridge, UK, 1991 (As Updated).10-2

Koch H, Weisser P. 1997. Exposure of honey bees during pesticide application under field conditions. Apidologie 28:439-447. doi: 10.1051/apido:19970610

Lewis W.J., van Lenteren J.C, Phatak Sharad C., Tumlinson J.H.1997. A total system approach to sustainable pest management Proc. Natl. Acad. Sci. Vol. 94, pp. $12243-12248$

Liu, T.P. 1995. A possible control of chalkbrood and Nosema diseases of the honeybee 
with neem. American Bee Journal. 135:195-198.

Melathopoulos, Adony P.; Winston, Mark L.; Whittington, Robin; Higo, Heather; and Le Doux, Monique. 2000. "Field Evaluation of Neem and Canola Oil for the Selective Control of the Honey Bee (Hymenoptera: Apidae) Mite Parasites Varroa jacobsoni (Acari: Varroidae) and Acarapis woodi (Acari: Tarsonemidae)." Journal of Economic Entomology 93.3 June. 559-567. Print

Mordue, J.A, and Blackwell, A. 1993. Azadirachtin: an Update. Journal of Insect Physiology. 39: 903-924.

Mullin CA, Frazier M, Frazier JL, Ashcraft S, Simonds R, et al. 2010. High Levels of Miticides and Agrochemicals in North American Apiaries: Implications for Honey Bee Health. PLoS ONE 5(3): e9754. doi:10.1371/journal.pone.0009754

Naumann, K. and Isman, M. B. 1996. Toxicity of a neem (Azadirachta indica A. Juss) insecticide to larval honey bees. American Bee Journal. 7: 518-520.

Osborne, Laurie. Florida Small Farms and Alternative Enterprises Conference: Introduction. University of Florida IFAS Extention. Accessed April 2010. http://smallfarms.ifas.ufl.edu/floridasmallfarmsconference/2010/index.shtml\#intro duction

Pettis, P.S., Shimanuki, H. 1999. A hive modification to reduce Varroa populations. American Bee journal. 143 (6): 471-473.

Public Broadcasting Service (PBS). 2009. "Silence of the Bees". Nature Series Episode. premiered October 28, 2007. Accessed September 20, 2010. http://www.pbs.org/wnet/nature/episodes/silence-of-the-bees/full-episode/251/

Rembold H., Sharma G K., Czoppelt C., and Schmutterer H. . Evidence of growth disruption in insects without feeding inhibition by neem azadirachta-indica seed fractions. Journal of Plant diseases and Protection. 87: 290-297. Cited in Schenk (2001).

Rosenkranz, P., Tewarson, N.C., Singh, A., Engels, W. 1993. Differential hygienic behavior towards Varroa jacobsoni in capped worker brood of Apis cerana depends on alien scent adhering to the mites. J. Apic. Res. 32 (2): 89-93

Schmuck R, Scho“ning R, Stork A, Schramel O (2001) Risk posed to honey bees (Apis mellifera L. Hymenoptera) by an imidacloprid seed dressing of sunflowers. Pest Manage Sci 57:225-238. doi:10.1002/ps.270 
Schuler, Tim. Fact Sheet: How to check for Varroa mites using the sugar shake method. State of New Jersey. Department of Agriculture. http://www.state.nj.us/agriculture/divisions/pi/pdf/varroamites.pdf

Schulz David J., Huang Zhi-Yong, Robinson Gene E. 1998. Effects of colony food shortage on behavioral development in honey bees. Behav Ecol Sociobiol 42: $295 \pm 303$

Tarpy, David R. and Gilley, David C. 2004. Group decision making during queen production. Apidologie. 207-216.

Tew, James E.; Heilman, David J.; Ferrell, Jason G. Fact Sheet: Controlling varroa mites in a bee hive. Ohio State University.

The Agrochemicals Handbook, Third Edition. 1994. Royal Society of Chemistry Information Systems. Unwin Brothers Ltd., Surrey, England.

The University of Arizona. Activity 12: Honeybee Math Questions. Africanized Honey Bee Education Project. Accessed June 2010. http://ag.arizona.edu/pubs/insects/ahb/act12.html

Thomson, W. T. 1983. Agricultural Chemicals Book I Insecticides. Thomson Publications. Fresno, CA.

United States Department of Agriculture (USDA). Natural Resources Conservation Service (NRCS). Using Farm Bill Programs for Pollinator Conservation. Washington DC. Technical Note No. 78 August 2008.

United States Department of Agriculture (USDA). Agriculture Research Service. Colony Collapse Disorder. 2009. http://www.ars.usda.gov/News/docs.htm?docid=15572

United States Fish \& Wildlife Service. "Integrated Pest Management: Reducing Risks to Pollinators from Pest Management Activities." Division of Environmental Quality. October 2006.

Villa S, Vighi M, Finizio A, Bolchi Serini G.2000. Risk assessment for honey bees from pesticide-exposed pollen. Ecotoxicology 9:287-297. doi:10.1023/A:1026522112328

Waller GD, Erickson BJ, Harvey J, Martin JH (1984) Effects of dimethoate on honey bees (Hymenoptera: Apidae) when applied to flowering lemons. J Econ Entomol 77:70-74. 